PNL-6114

UC-245

$181+$

\title{
Bench-Scale Studies on Fluid-Bed Pyrolysis of Wood
}

L. K. Mudge

M. D. Brown

W. A. Wilcox

August 1988

Prepared for the

Biofuels and Municipal Waste

Technology Division

U.S. Department of Energy

under Contract DE-AC06-76RLO 1830

Pacific Northwest Laboratory

Operated for the U.S. Department of Energy

by Battelle Memorial Institute 


\section{DISCLAIMER}

This report was prepared as an account of work sponsored by an agency of the United States Government. Neither the United States Government nor any agency thereof, nor Battelle Memorial Institute, nor any or their employees, makes any warranty, expressed or implied, or assumes any legal liability or responsibility for the accuracy, completeness, or usefulness of any information, apparatus, product, or process disclosed, or represents that its use would not infringe privately owned rights. Reference herein to any specific commercial product, process, or service by trade name, trademark, manufacturer, or otherwise does not necessarily constitute or imply its endorsement, recommendation, or favoring by the United States Government or any agency thereof, or Battelle Memorial Institute. The views and opinions of authors expressed herein do not necessarily state or reflect those of the United States Government or any agency thereof, or Battelle Memorial Institute.

\section{PACIFIC NORTHWEST LABORATORY operated by BATTELLE MEMORIAL INSTITUTE for the UNITED STATES DEPARTMENT OF ENERGY under Contract DE-AC06-76RLO 1830}

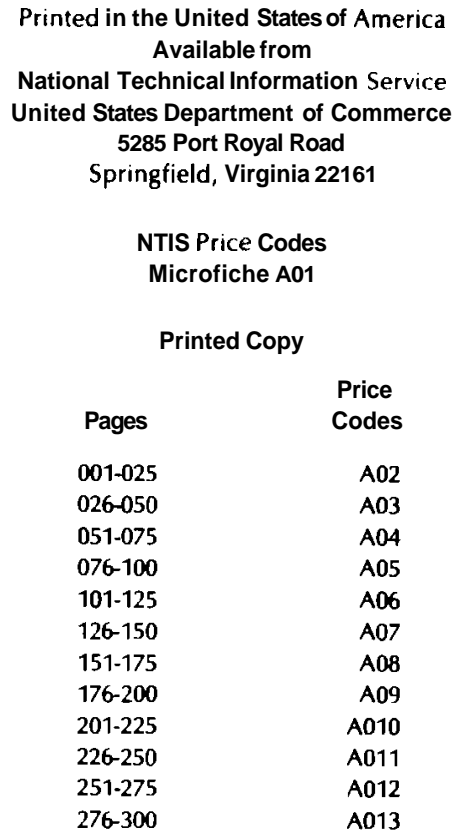


BENCH-SCALE STUDIES ON FLUID-BED

PYROLYSIS OF WOO

\author{
L. K. Mudge \\ M. D. Brown \\ W. A. Wilcox
}

August 1988

Prepared for the

Biofuels and Municipal Waste Technology Division U.S. Department of Energy under Contract DE-AC06-76RLO 1830

Pacific Northwest Laboratory

Richland, Washington 99352 
SUMMARY

Results of bench-scale studies on fluid-bed pyrolysis of wood with carbon dioxide $\left(\mathrm{CO}_{2}\right)$, methane $\left(\mathrm{CH}_{4}\right)$, and hydrogen $\left(\mathrm{H}_{2}\right)$ contact gases are described in this report. The primary objective of these studies was to determine the effect of thermal treatment with these gases on product yields, primarily yield of condensible hydrocarbons. The results of these studies were analyzed to determine the effects of temperature, contact gas, wood feed rate, and gas contact time on the yields of gases, liquids, and char. The yield of condensible organics is compared to the yield from steam gasification.

Fluid-bed pyrolysis tests with each of the contact gases were conducted at temperatures from $650^{\circ} \mathrm{C}\left(1200^{\circ} \mathrm{F}\right)$ to $800^{\circ} \mathrm{C}\left(1470^{\circ} \mathrm{F}\right)$ and gas residence times of 1 and $2 \mathrm{~s}$. The wood feed rate varied between 1 and $1.4 \mathrm{~kg} / \mathrm{h}(2$ and $3 \mathbf{l b} / \mathbf{h})$. Results reported for the different contact gases $\left(\mathrm{CH}_{4}, \mathrm{CO}_{2}\right.$, and $\left.\mathrm{H}_{2}\right)$ are based on data from a single test at each set of experimental conditions. Consequently, yields at each set of conditions were not verified. Data from these single tests indicate general trends. These trends are not of sufficient significance to justify additional experiments at this time.

Variations of the wood feed rate had no effect on product yields within the range of rates tested. Decreasing the gas residence time showed slight trends toward reduced yields of gas and char and increased yield of condensible organics.

In tests with $\mathrm{H}_{2}$ and $\mathrm{CH}_{4}$, samples of condensible hydrocarbons were collected by three methods: 1) scrubbing the entire product gas with water at room temperature, 2) scrubbing a gas slipstream with methylene chloride $(\mathrm{MeCl})$ at $0^{\circ} \mathrm{C}\left(32^{\circ} \mathrm{F}\right)$, and 3) hydrocarbons from a slipstream scrubbed at $-20^{\circ} \mathrm{C}$ $\left(-4^{\circ} \mathrm{F}\right)$. Total weight yield of condensible hydrocarbons was determined from the weight collected at $-20^{\circ} \mathrm{C}\left(-4^{\circ} \mathrm{F}\right)$ less the weight of water in the gas stream. In tests with $\mathrm{CO}_{2}$ a secondary bed of zeolite catalyst was used, and condensibles were collected in the MeCl scrubbers only. The MeCl scrub solutions were subjected to gas chromatography analysis for determination of $\mathrm{C}_{6}-\mathrm{C}_{20}$ hydrocarbons. Analyses indicated that only from $13 \%$ to $20 \%$ of the 
benzene/toluene/xylene fraction was col lected by scrubbing the gas stream at room temperature compared to the quantity collected at $-20^{\circ} \mathrm{C}\left(-4^{\circ} \mathrm{F}\right)$.

At $725^{\circ} \mathrm{C}\left(1340^{\circ} \mathrm{F}\right)$, the yield of condensible organics collected in the $\mathrm{MeCl}$ scrubbers showed a slight trend with $\mathrm{CH}_{4}>\mathrm{H}_{2} \mathrm{O}>\mathrm{CO}_{2}=\mathrm{H}_{2}$. Results with $\mathrm{CH}_{4}, \mathrm{CO}_{2}$, and $\mathrm{H}_{2}$ are from single tests, whereas results with $\mathrm{H}_{2} \mathrm{O}$ are the average of 15 tests.

Results are reported showing the effects of operating conditions with different contact gases on yields of condensibles, gases, and char. The general trends shown by the data should aid analysis of different thermal treatment methods for influencing the yield of tars in biomass-deri ved gases and should be helpful in determining the effect of using recycle gas for wood gasification. 


\section{ACKOMEDGNENIS}

This report summarizes technical results of bench-scale studies on fluid-bed pyrolysis of wood. The work was funded by the Biofuels and Municipal Waste Technology Division of the U.S. Department of Energy (DOE). The guidance and support provided by Gary F. Schiefelbein and Mark A. Gerber of the Program Office at Pacific Northwest Laboratory and Simon Friedrich of DOE are greatly appreciated. 


\section{CONTENTS}

SUMMARY ...............................

ACKNOWLEDGMENTS ...................

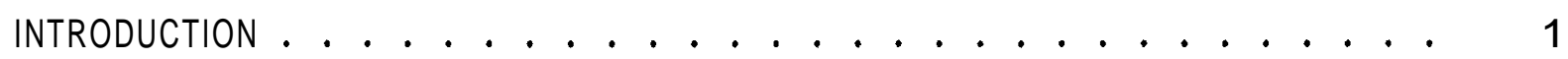

EXPERIMENTAL BENCH-SCALE EQUIPMENT ............. 3

EXPERIMENTAL RESULTS ................... . . 7

TESTS WITH CARBON DIOXIDE ............. 8

TESTS WITH METHANE .............................. 12

TESTS WITH HYDROGEN . . . . . . . . . . . . . . 16

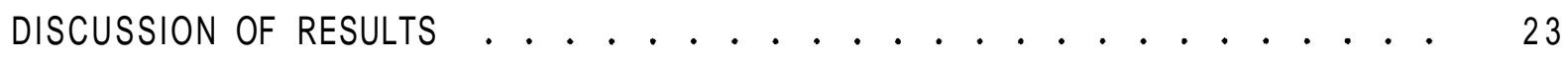

EFFECT OF TEMPERATURE ON YIELD OF CONDENSIBLES . . . . . . 23

EFFECT OF TEMPERATURE ON GAS YIELD . . . . . . . . . . 26

EFFECT OF CONTACT GAS . . . . . . . . . . . . . . 30

EFFECT OF GAS CONTACT TIME . . . . . . . . . . . . . . . 35

EFFECT OF WOOD FEED RATE ...................... 36

CONCLUSIONS AND RECOMMENDATIONS .............. 39

REFERENCES ............................ 41

APPENDIX ...................... A.I 


\section{FIGURES}

Equipment Arrangement for Dual-Vessel Tests . . . . . . . . . 3

Equipment Schematic for Single-Vessel Tests . . . . . . . . 5

Effect of Temperature. Contact Gas. and Gas Velocity on

Yield of Condensible Organics . . . . . . . . . . . . . 24

Effect of Operating Conditions on Yield of Condenser Oils . . . 25

Effect of Operating Conditions on Yield of Aqueous

Soluble Organics ................ 26

Effect of Temperature and Contact Gases on Benzene/Toluene/

Xylene Yield in Methylene Chloride Scrub Solutions .......

Effect of Temperature and Contact Gas on Yield of

$\mathrm{C}_{6}-\mathrm{C}_{20}$ Organics...................... 28

Effect of Temperature on Gas Yield ........... 29

Effect of Temperature and Contact Gas on Yield of Carbon

Monoxide .................... . 30

Effect of Temperature and Contact Gas on Yield of

Carbon Dioxide .................... 31

11 Effect of Temperature and Contact Gas on Yield of Methane . . . 32

12 Effect of Temperature and Contact Gas on Yield of Hydrogen . . . 33

13 Effect of Temperature. Contact Gas. and Gas Velocity on Yield of char ........................ 34

Effect of Contact Gas on Yield of Condensible Organics .... 35

Effect of Wood Feed Rate on Gas Yield . . . . . . . . . . . 37 


\section{$\underline{\text { TABLES }}$}

1 Analysis of Feedstock . . . . . . . . . . . . 6

2 Yields with Carbon Dioxide Contact Gas ........... 8

3 Weight Yields with Carbon Dioxide Contact Gas . . . . . . . . 9

4 Effect of Carbon Dioxide Flow on Gas Yield . . . . . . . . 10

5 Yield of Organics in Methylene Chloride Solution . . . . . . 11

6 Gas Composition and Yield with Carbon Dioxide Contact Gas . . . . 12

7 Yields with Methane Contact Gas . . . . . . . . . . . 13

8 Gas Composition and Yield with Methane Contact Gas . . . . . . 14

9 Effect of Methane Flow on Gas Yield ............. 15

10 Condenser 0 il Yield with Methane Contact Gas . . . . . . . 16

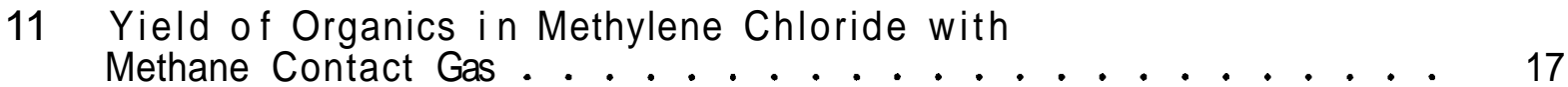

12 Yields with Hydrogen Contact Gas . . . . . . . . . 18

13 Gas Composition and Yield with Hydrogen Contact Gas . . . . . . . 19

14 Yield of Condenser Oils with Hydrogen Contact Gas . . . . . . 20

15 Yield of Organics in Methylene Chloride with Hydrogen Contact Gas ... . . . . . . . . 21

16 Percentage of $\mathrm{C}_{6}-\mathrm{C}_{20}$ Components in Condenser $\mathrm{O} i \mathrm{i} \ldots{ }_{28}$ 


\section{INTRODUCTION}

Pacific Northwest Laboratory (PNL) is conducting studies to improve the conversion efficiency of biomass gasification. These studies are sponsored by the Biofuels and Municipal Waste Technology Division of the U.S. Department of Energy (DOE). Part of the research includes thermal conversion of biomass by fluid-bed contact with gases not commonly used for gasification to determine their effect on product yields.

Commercial gasification processes convert carbonaceous matter, incl uding biomass, into fuel gases and some condensible liquids (Von Fredersdorff and Elliot 1963; Fritz, Gordon, and Nguyen 1979). Although there are exceptions with some refractory carbonaceous materials, the residues from gasification processes comprise principally the inert mineral constituents of the feedstock. These residues are essentially devoid of significant quantities of carbon. In contrast, residues from pyrolysis, which results from biomass contact at high temperatures with nonreactive gases such as those used in this study, contain a substantial quantity of carbon from the original feedstock. These residues are classified as char.

Both gasification and pyrolysis of carbonaceous materials produce a mixture of gaseous products as a result of the complex parallel, competitive, and sequential reactions. Alternative thermal treatment methods, such as recycle of combustion gases to the process, can influence the composition of gaseous products. Of particular interest is the effect of these alternative methods on the yield from biomass of condensible hydrocarbons in wastewater treatment systems. Condensible hydrocarbons can plug lines and deposit on downstream equipment and thus adversely affect wastewater treatment and environmental control.

The primary objective of this study was to determine the effects of different contact gases and experimental conditions on product yields from fluid-bed wood pyrolysis. The yield of condensible hydrocarbons was of particular interest. The contact gases employed included carbon dioxide $\left(\mathrm{CO}_{2}\right)$, methane $\left(\mathrm{CH}_{4}\right)$, and hydrogen $\left(\mathrm{H}_{2}\right)$. Reaction temperatures ranged from $650^{\circ} \mathrm{C}$ to $800^{\circ} \mathrm{C}$, and gas contact time was between 1 and $2 \mathrm{~s}$. Tests with $\mathrm{CO}_{2}$ 
contact gas used a secondary vessel of catalyst for cracking of condensibles generated in the primary gasifier. Results of earl ier studies at PNL (Mudge, Sealock, and Weber 1979; Mitchell et al. 1980; Mudge et al. 1981, 1983; Baker and Mudge 1986) showed the effectiveness of various catalysts for destruction of condensible hydrocarbons.

Analyses of results on the effects of contact gas, reaction temperature, gas contact time, and wood feed rate are presented in this report, along with a description of experimental equipment and methods. Data were obtained from single tests at each set of experimental conditions. Conditions were not repeated to determine the amount of experimental error. Material balance closures were generally quite good for the experimental tests, within $10 \%$ A complete listing of all data collected in the tests is given in the appendix, along with definitions of table entries. 


\section{EXPERIMENTAL BENCH-SCALE EQUIPMENT}

Bench-scale equipment, shown schematically in Figure 1, was used in these studies. A detailed description of the equipment and operating procedures is presented in an earlier report (Mudge et al. 1983).

The gasifier was fabricated from a 2-ft $(61 \mathrm{~cm})$ length of $3-\mathrm{in} .(7.6 \mathrm{~cm})$ Sch $40304 \mathrm{~L}$ stainless steel pipe and a $1-\mathrm{ft}(30 \mathrm{~cm})$ length of $5-\mathrm{in} .(12.7 \mathrm{~cm})$ Sch 40 pipe. A bed depth of $1 \mathrm{ft}(30 \mathrm{~cm})$ was maintained by vacuum withdrawal of bed material during operation of the gasifier as a fluidized bed. The upper enlarged section of the gasifier was provided for de-entrainment of sol ids.

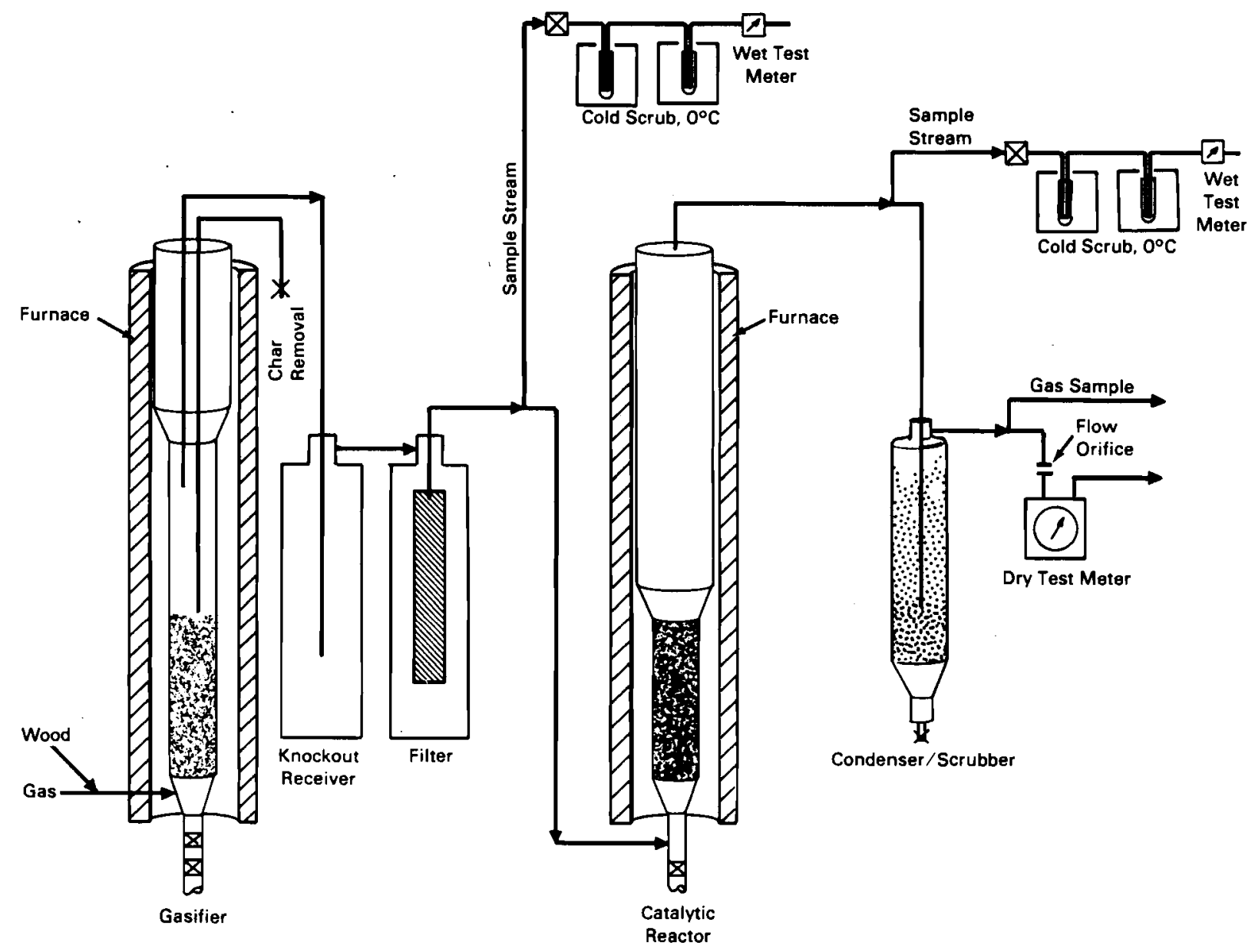

FIGURE 1. Equipment Arrangement for Dual-Vessel Tests 
Wood mixed with sand was auger fed continuously into a 1-in. $(2.5 \mathrm{~cm})$ tube where it was entrained by the fluidizing gases and carried into the gasifier. Sand was mixed with the wood to replace inert solids lost from the bed during fluid-bed operation.

Tests with different contact gases were completed at temperatures from $1200^{\circ} \mathrm{F}\left(650^{\circ} \mathrm{C}\right)$ to $1470^{\circ} \mathrm{F}\left(800^{\circ} \mathrm{C}\right)$. Gas contact time in the tests ranged from 1 to $2 \mathrm{~s}$.

The primary emphasis of the tests was to determine the effect of contact gases and operating conditions on yields and compositions of condensible organics. Initial tests were completed with $\mathrm{CO}_{2}$ as the contact gas with the configuration shown in Figure 1. A measured gas sample, which represented about $1 \%$ of the total gas flow, was taken before and after the secondary vessel and passed through two scrubbers (shown as "cold scrub, $0^{\circ} \mathrm{C}$ " in Figure 1) in series filled with methylene chloride (MeC1) and maintained at $32^{\circ} \mathrm{F}\left(0^{\circ} \mathrm{C}\right)$. The $\mathrm{MeCl}$ solutions were then analyzed by gas chromatography (GC) to determine organic yields and compositions. A zeolite, LZ-Y82, was used in the secondary vessel maintained at a temperature of $1020^{\circ} \mathrm{F}\left(550^{\circ} \mathrm{C}\right)$.

Nitrobenzaldehyde was used as an internal standard to analyze for organics in the MeCl solution. This method did not identify all the condensible organics generated in the test. With the arrangement shown in Figure 1, condensible organic yields could be verified independently only from the secondary vessel by analysis of condensate collected at about $80^{\circ} \mathrm{F}\left(27^{\circ} \mathrm{C}\right)$. Most of the condensible organics produced in the gasifier were destroyed in the secondary catalyst bed. Tests with $\mathrm{H}_{2}$ and $\mathrm{CH}_{4}$ were therefore conducted with the configuration shown in Figure 2. A separate measured slipstream sample was passed through a small scrubber maintained at $-4^{\circ} \mathrm{F}\left(-20^{\circ} \mathrm{C}\right)$. The scrubber was weighed before and after each test to determine the yield of all condensibles.

With the arrangement shown in Figure 2, yield could also be verified by analysis of condensate from the condenser/scrubber and by collection of condensate at $-4^{\circ} \mathrm{F}\left(-20^{\circ} \mathrm{C}\right)$. Condensate from the condenser scrubber was drained and allowed to settle at least $24 \mathrm{~h}$ before the phases were separated by decantation. The total organic carbon was determined for the aqueous phase, 


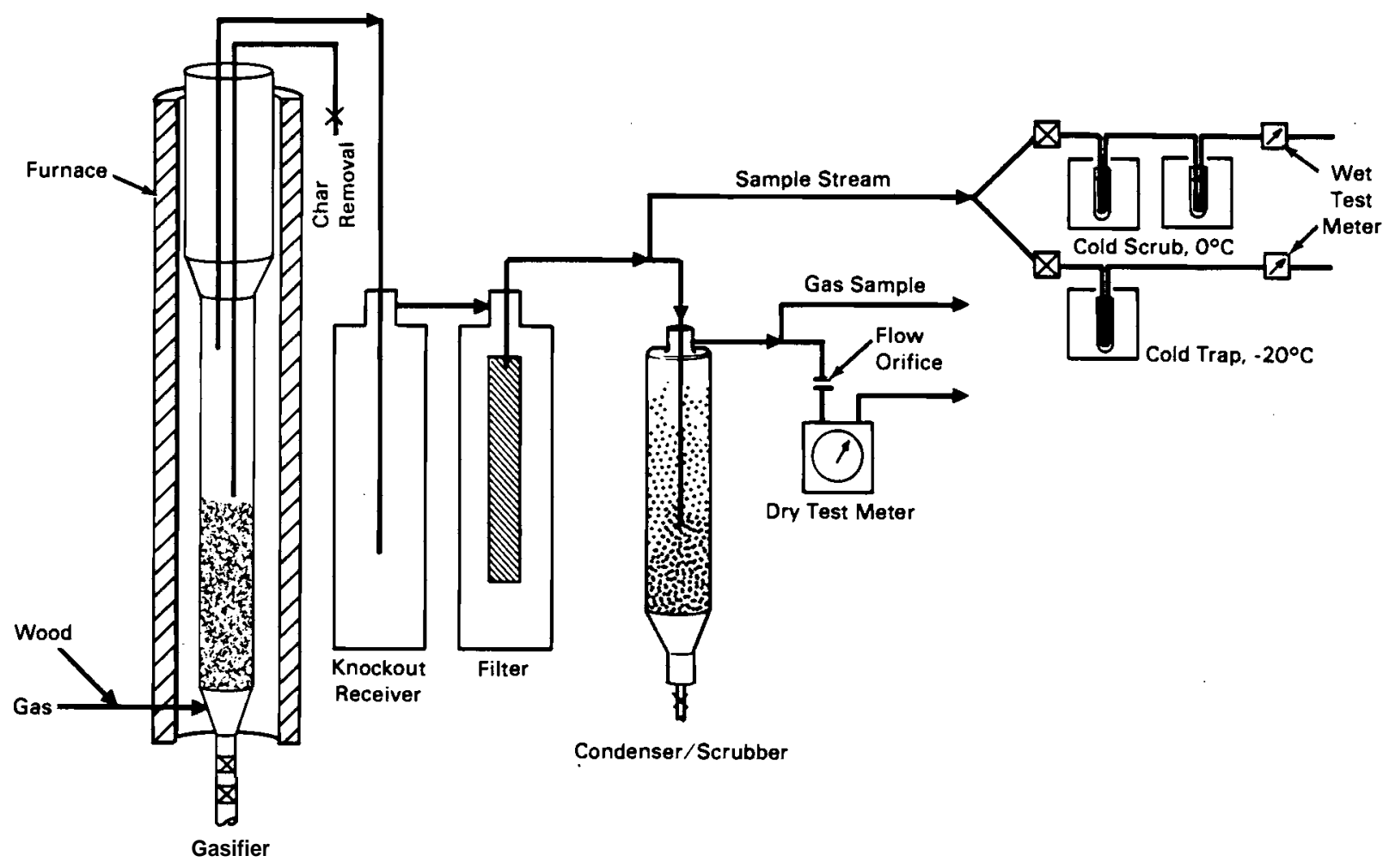

FGURE 2. Equipment Schematic for Single-Vessel Tests

and the organic phase was analyzed for $\mathrm{C}, \mathrm{H}$, and $\mathbf{N}$. In Figure 2, MeCl was used in the "cold scrub, $0^{\circ} \mathrm{C} . "$ For material balance purposes, the watersoluble organics were assumed to have the same elemental composition as wood.

The feedstock used in these studies was densified pine flakes obtained from Thomas A. Miles Consulting Engineers, Portland, Oregon. Analysis of the feedstock is presented in Table 1 . Screen size used in the tests was -14 U.S. Sieve No. Wood was dried at $100^{\circ} \mathrm{C}$ overnight and was considered to be completely dry for material balance calculations. Tests with this material gave results identical to previous tests with sawdust.

Silica sand obtained from Martin Marietta Industrial Sand Division was used to stabilize the fluid bed. The sand was $99.88 \%$ silica with a bulk density of $1001 \mathrm{~b} / \mathrm{ft}^{3}\left(1.6 \mathrm{~g} / \mathrm{cm}^{3}\right)$ in the size range of -30 to +100 U.S. Sieve No. (0.42 to $0.21 \mathrm{~mm})$. 
TABLE 1. Analysis of Feedstock

\begin{tabular}{lr} 
Element & $\begin{array}{c}\text { Weight } \\
\text { Percent }\end{array}$ \\
$\mathrm{C}$ & 50.3 \\
$\mathrm{H}$ & 6.4 \\
O (by diff) & 42.7 \\
Ash & 0.6 \\
\multicolumn{2}{c}{ Hiqher Heating Value }
\end{tabular}

8,770 Btu/lb

$20,400 \mathrm{~kJ} / \mathrm{kg}$ 


\section{EXPERIMENTAL RESULTS}

Results of tests with $\mathrm{CO}_{2}, \mathrm{CH}_{4}$, and $\mathrm{H}_{2}$ contact gases are presented in this section. Conditions used in these tests were temperatures from $650^{\circ} \mathrm{C}$ to $800^{\circ} \mathrm{C}\left(1200^{\circ} \mathrm{F}\right.$ to $\left.1470^{\circ} \mathrm{F}\right)$, gas contact times from 1 to $2 \mathrm{~s}$, and wood flow rates from 2 to $3 \mathrm{lb} / \mathrm{h}(0.9$ to $1.4 \mathrm{~kg} / \mathrm{h})$.

The results are based on data from single tests at each set of experimental conditions. In tests with $\mathrm{CO}_{2}$ contact gas, a secondary bed of zeolite catalyst was used (see Figure 1). Condensible organics were destroyed by the bed of catalyst, which complicated analysis of yields from $\mathrm{CO}_{2}$ pyrolysis for two reasons: 1) the gas volume from the primary bed was unknown since the measured volume from the secondary bed included gases generated by destruction of tars, and 2) condensible organics could not be collected in the condenser/scrubber since they were partiall y destroyed. For these reasons, subsequent tests with $\mathrm{CH}_{4}$ and $\mathrm{H}_{2}$ did not include a secondary bed of catalyst.

In the results below, three fractions of condensibles are reported: 1) the fraction collected in $\mathrm{MeCl}$ scrubbers, 2) the fraction collected in a cold trap at $-4^{\circ} \mathrm{F}\left(-20^{\circ} \mathrm{C}\right)$, and 3$)$ the fraction collected in the condenser/ scrubber at about $80^{\circ} \mathrm{F}\left(27^{\circ} \mathrm{C}\right)$. Fraction 1 was identified in all tests with $\mathrm{CO}_{2}, \mathrm{CH}_{4}$, and $\mathrm{H}_{2}$ and included the $\mathrm{C}_{6}-\mathrm{C}_{20}$ fraction. Fraction 2 was the condensate collected at $-4^{\circ} \mathrm{F}\left(-20^{\circ} \mathrm{C}\right)$, which included water vapor in the gas stream. Water vapor per unit weight of wood was determined from the weight of aqueous phase collected in the condenser/scrubber and the weight of water vapor in the saturated gases leaving the condenser/scrubber. In tests with $\mathrm{CH}_{4}$ and $\mathrm{H}_{2}$, the weight of condensible organics per unit weight of wood was calculated by subtracting the weight of water per unit weight of wood from the weight of condensate collected at $-4^{\circ} \mathrm{F}\left(-20^{\circ} \mathrm{C}\right)$ per unit weight of wood. The fraction reported in the tables as "wt\% cond org" (weight percent condensible organics) included all organics (such as acetic acid and methanol plus organics collected in the $\mathrm{MeCl}$ scrubbers) that condense above $-4^{\circ} \mathrm{F}$ $\left(-20^{\circ} \mathrm{C}\right)$. Fraction 3 included the condensate collected in the condenser/ scrubber at about $80^{\circ} \mathrm{F}\left(27^{\circ} \mathrm{C}\right)$ and analyzed as described in the previous section. 


\section{TESTS WITH CARBON DIOXIDE}

Tests with $\mathrm{CO}_{2}$ as the contact gas were completed with a secondary bed of LZ-Y82 catalyst and the equipment flow configuration shown in Figure 1.

Results from these tests are presented in Table 2, which shows the yields of gases, char, and condensibles from the gasifier. These same yields after

TABLE 2. Yields with Carbon Dioxide Contact Gas ${ }^{(a)}$

\begin{tabular}{|c|c|c|c|c|c|c|c|}
\hline & & & INUm & Gas & emp & & \\
\hline Yields & $\begin{array}{l}\mathrm{LC}-1 \\
(650) \\
\end{array}$ & $\begin{array}{l}\text { LC-2 } \\
(700)\end{array}$ & $\begin{array}{r}\text { LC-5 } \\
(700) \\
\end{array}$ & $\begin{array}{r}\text { LC-7 } \\
(750) \\
\end{array}$ & $\begin{array}{r}\text { LC-6 } \\
(750) \\
\end{array}$ & $\begin{array}{r}\text { LC-4 } \\
(800) \\
\end{array}$ & $\begin{array}{r}\text { LC-3 } \\
(800) \\
\end{array}$ \\
\hline $\operatorname{siv}$, (b) $\mathrm{ft} / \mathrm{s}$ & 0.96 & 1.01 & 1.40 & 0.92 & 1.46 & 1.16 & 1.53 \\
\hline gas cont time, $s$ & 2.1 & 2.0 & 1.4 & 2.2 & 1.4 & 1.7 & 1.3 \\
\hline wt $\mathrm{CO}_{2} /$ wt wood & 3.2 & 3.0 & 4.2 & 1.5 & 4.0 & 3.5 & 4.2 \\
\hline $1 \mathrm{~b}$ wood $/ \mathrm{h}-\mathrm{ft}^{3}$ & 40 & 42 & 42 & 71 & 44 & 39 & 42 \\
\hline$w t \%$ dry gas & 52 & 62 & 63 & 71 & 84 & 74 & 74 \\
\hline$\%$ C in gas & 45 & 55 & 59 & 65 & 75 & 71 & 71 \\
\hline$\% \mathrm{H}$ in dry gas & 40 & 47 & 48 & 58 & 60 & 63 & 61 \\
\hline$\% 0$ in dry gas & 61 & 71 & 70 & 79 & 98 & 78 & 78 \\
\hline wt\% char & 8 & 6 & 6 & 7 & 5 & 2 & 3 \\
\hline$\%$ C in char & 14 & 11 & 10 & 12 & 8 & 4 & 5 \\
\hline$\% \mathrm{H}$ in char & 1.30 & 0.96 & 0.93 & 1.12 & 0.70 & 0.36 & $0.4 \varepsilon$ \\
\hline$\% 0$ in char & 2.70 & 1.99 & 1.93 & 2.33 & 1.44 & 0.74 & 0.99 \\
\hline$w t \%$ in $C_{6}-C_{20}$ & 3.50 & 2.93 & 3.21 & 3.74 & 5.65 & 6.36 & 6.08 \\
\hline$\% C$ in $C_{6}-C_{20}$ & 5.95 & 4.98 & 5.45 & 6.36 & 9.61 & 10.81 & 10.34 \\
\hline$\% \mathrm{H}$ in $\mathrm{C}_{6}-\mathrm{C}_{20}$ & 3.34 & 2.79 & 3.06 & 3.57 & 5.39 & 6.06 & 5.80 \\
\hline$\%$ water soluble C & 1.31 & 0.86 & 0.89 & 0.76 & 0.85 & 0.87 & 0.92 \\
\hline wt $\% \mathrm{H}_{2} \mathrm{O}$ & 14 & 12 & 15 & 9 & 13 & 10 & 13 \\
\hline$\% \mathrm{H}$ in water & 23 & 20 & 25 & 15 & 22 & 18 & 23 \\
\hline$\% 0$ in water & 27 & 24 & 30 & 18 & 26 & 21 & 27 \\
\hline C balance, $\%$ & 67 & 71 & 75 & 85 & 93 & 87 & 88 \\
\hline $\mathrm{H}$ balance, $\%$ & 67 & 71 & 77 & 78 & 88 & 87 & 90 \\
\hline 0 balance, $\%$ & 91 & 96 & 101 & 100 & 126 & 100 & 106 \\
\hline
\end{tabular}

(a) All yields are based on weight of wood feed.

(b) Superficial 7 inear velocity. 
catalytic treatment at $550^{\circ} \mathrm{C}$ in the secondary vessel are included in the appendix. The elemental yields are based on the $\mathrm{C}, \mathrm{H}$ and $\mathrm{O}$ in the input wood. It must be noted that the gas volume from the primary vessel is unknown since the volume measured by the dry test meter (see Figure 1) is after catalytic treatment, which destroys tars and increases gas volume. This volume was used as the gas volume from the primary vessel to estimate yields, which probably overestimates the gas yield from the primary vessel. The superficial linear velocity (slv) is based on the empty cross section of the reactor at reactor temperature and pressure. An slv of $1 \mathrm{ft} / \mathrm{s}(30 \mathrm{~cm} / \mathrm{s})$ corresponds to a gas residence time at reactor temperature of about $2 \mathrm{~s}$. The gasifier was operated with a $1-\mathrm{ft}(30 \mathrm{~cm})$ bed depth and a wood feed rate of $2 \mathrm{~b} / \mathrm{h}(0.9 \mathrm{~kg} / \mathrm{h})$, which gives a rate based on reactor volume of $401 \mathrm{~b} / \mathrm{h}-\mathrm{ft}^{3}$ $\left(640 \mathrm{~kg} / \mathrm{h} \cdot \mathrm{m}^{3}\right)$.

For tests with $\mathrm{CO}_{2}$ as the contact gas at $650^{\circ} \mathrm{C}$ and $700^{\circ} \mathrm{C}\left(1200^{\circ} \mathrm{F}\right.$ and $1290^{\circ} \mathrm{F}$ ), material balances for $\mathrm{C}, \mathrm{H}$, and 0 were less than usually obtained with the bench-scale equipment, as shown in Table 2. Part of the problem could be errors in determining the input gas flows. It appears, however, that all condensibles were not collected or identified. Weight yields of gases, char, and condensibles are listed in Table 3 . The water yield includes water in the gas saturated at the temperature of the condenser. The char yield, which is low, is determined quite accurately by weighing and analyzing the chars collected in the knockout receiver and filter (see

TABLE 3. Weight Yields with Carbon Dioxide Contact Gas

\begin{tabular}{|c|c|c|c|c|c|c|c|}
\hline Yields & $\begin{array}{l}\mathrm{LC}-1 \\
(650) \\
\end{array}$ & $\begin{array}{l}\text { LC-2 } \\
(700) \\
\end{array}$ & $\begin{array}{l}\text { LC-5 } \\
(700) \\
\end{array}$ & $\begin{array}{l}\text { LC-7 } \\
(750) \\
\end{array}$ & $\begin{array}{l}\text { LC-6 } \\
(750) \\
\end{array}$ & $\begin{array}{r}L C-4 \\
(800) \\
\end{array}$ & $\begin{array}{r}\text { LC-3 } \\
(800) \\
\end{array}$ \\
\hline $\mathrm{slv}, \mathrm{ft} / \mathrm{s}$ & 0.86 & 0.85 & 1.18 & 0.74 & 1.18 & 0.89 & 1.18 \\
\hline$w t \%$ dry gas & 54 & 59 & 67 & 71 & 71 & 81 & 81 \\
\hline$w t \%$ char & 8 & 6 & 6 & 7 & 5 & 2 & 3 \\
\hline$w t \% C_{6}-C_{20}$ & 2.75 & 4.12 & 6.85 & 4.14 & 4.51 & 6.26 & 6.01 \\
\hline$w t \% \mathrm{H}_{2} \mathrm{O}$ & 14 & 12 & 15 & 9 & 13 & 10 & 13 \\
\hline$w t \%$ aq sol org & 1 & 1 & 1 & 1 & 1 & 1 & 1 \\
\hline Total wt \% rec & 80 & 82 & 95 & 92 & 94 & 101 & 105 \\
\hline
\end{tabular}


Figure 1) and in the fluid bed before and after each test. The net weight yield of gases is strongly influenced by the measured input rate of $\mathrm{CO}_{2}$, as discussed below and shown in Table 4. If the measured input is erroneously high, the weight yield of gas will be low. Since accountability improves with temperature as the gas yield increases, it appears that the main problem must have been the collection and analysis of condensibles. Carbon balances shown in Table 2 are much less than the weight accountabilities shown in Table 3.

An error in the measurement of the $\mathrm{CO}_{2}$ flow rate significantly influences gas phase elemental yields calculated for carbon and oxygen. Table 4 shows the magnitude of a $5 \%$ error in determining the $\mathrm{CO}_{2}$ flow on the yields of wood carbon and oxygen to the gas phase. For example, in Test LC-3, a

TABLE 4. Effect of Carbon Dioxide Flow on Gas Yield ${ }^{(a)}$

\begin{tabular}{|c|c|c|c|c|c|c|c|}
\hline \multirow[b]{2}{*}{ Yields } & \multicolumn{7}{|c|}{ Test Number (Gasifier Temp, ${ }^{\circ} \mathrm{C}$ ) } \\
\hline & $\begin{array}{l}\mathrm{LC}-1 \\
(650)\end{array}$ & $\begin{array}{l}\mathrm{LC}-2 \\
(700)\end{array}$ & $\begin{array}{l}L C-5 \\
(700) \\
\end{array}$ & $\begin{array}{l}\text { LC-7 } \\
(750) \\
\end{array}$ & $\begin{array}{l}\text { LC-6 } \\
(750)\end{array}$ & $\begin{array}{l}\text { LC-4 } \\
(800)\end{array}$ & $\begin{array}{l}\text { LC-3 } \\
(800)\end{array}$ \\
\hline Meas. $\mathrm{L} / \mathrm{min} \mathrm{CO}_{2}$ & 25.9 & 25.7 & 35.7 & 22.3 & 35.5 & 26.9 & 35.5 \\
\hline wt $\%$ dry gas & 52 & 59 & 67 & 71 & 71 & 74 & 81 \\
\hline$\% c$ in gas & 45 & 54 & 59 & 65 & 66 & 71 & 75 \\
\hline$\% \mathrm{H}$ in dry gas & 40 & 52 & 41 & 56 & 53 & 63 & 59 \\
\hline$\% 0$ in dry gas & 61 & 66 & 79 & 78 & 80 & 78 & 91 \\
\hline $\mathrm{L} / \min \mathrm{CO}_{2}+5 \%$ & 27.20 & 26.99 & 37.49 & 23.42 & 37.28 & 28.25 & 37.28 \\
\hline wt $\%$ dry gas & 38 & 44 & 46 & 63 & 52 & 64 & 60 \\
\hline$\% C$ in gas & 38 & 46 & 47 & 60 & 55 & 66 & 64 \\
\hline$\% \mathrm{H}$ in dry gas & 41 & 52 & 41 & 56 & 53 & 55 & 59 \\
\hline$\% 0$ in dry gas & 37 & 41 & 45 & 66 & 47 & 62 & 56 \\
\hline $\mathrm{L} / \mathrm{min} \mathrm{CO}_{2}-5 \%$ & 24.61 & 24.42 & 33.92 & 21.19 & 33.73 & 25.56 & 33.73 \\
\hline wt $\%$ dry gas & 70 & 74 & 88 & 78 & 91 & 98 & 102 \\
\hline$\% C$ in gas & 55 & 62 & 70 & 69 & 77 & 84 & 87 \\
\hline$\% \mathrm{H}$ in dry gas & 41 & 52 & 41 & 56 & 53 & 55 & 59 \\
\hline$\% 0$ in dry gas & 91 & 92 & 114 & 91 & 113 & 119 & 125 \\
\hline
\end{tabular}

(a) All yields are based on weight of wood feed. 
measured $\mathrm{CO}_{2}$ flow rate that is $5 \%$ too high gave a $\% \mathrm{C}$ in gas (based on $\mathrm{C}$ in wood) and a \% 0 in gas (based on 0 in wood) of 64 and 56, respectively. These respective values changed to 87 and 125 for a measured $\mathrm{CO}_{2}$ flow rate that is $5 \%$ too low. Pressure fluctuations and gas cooling caused by evaporation of $\mathrm{CO}_{2}$ made control1ing the $\mathrm{CO}_{2}$ rate difficult. Calculations in Table 4 show that the measured $\mathrm{CO}_{2}$ flow drastically affects elemental balances for $\mathrm{C}$ and 0 . However, flow measurement should be we11 within the 5\% error level. The sensitivity of material balance calculations to gas flow led to abandonment of the two-vessel system to allow checking of yield of condensibles.

The yield of condensible organics from the primary gasifier identified by GC analysis of the MeCl scrub solutions is presented in Table 5. This was the only organic yield determined from the $\mathrm{CO}_{2}$ tests since the catalyst destroyed organic condensibles before they could be collected in the scrubber.

Gas composition and yield with $\mathrm{CO}_{2}$ as the contact gas are shown in Table 6. Error in the measurement of $\mathrm{CO}_{2}$ flow rate would affect the net $\mathrm{CO}_{2}$ yield only. Nitrogen was used as a purge gas in the wood feed hopper.

TABLE 5. Yield of Organics in Methylene Chloride Solution(a)

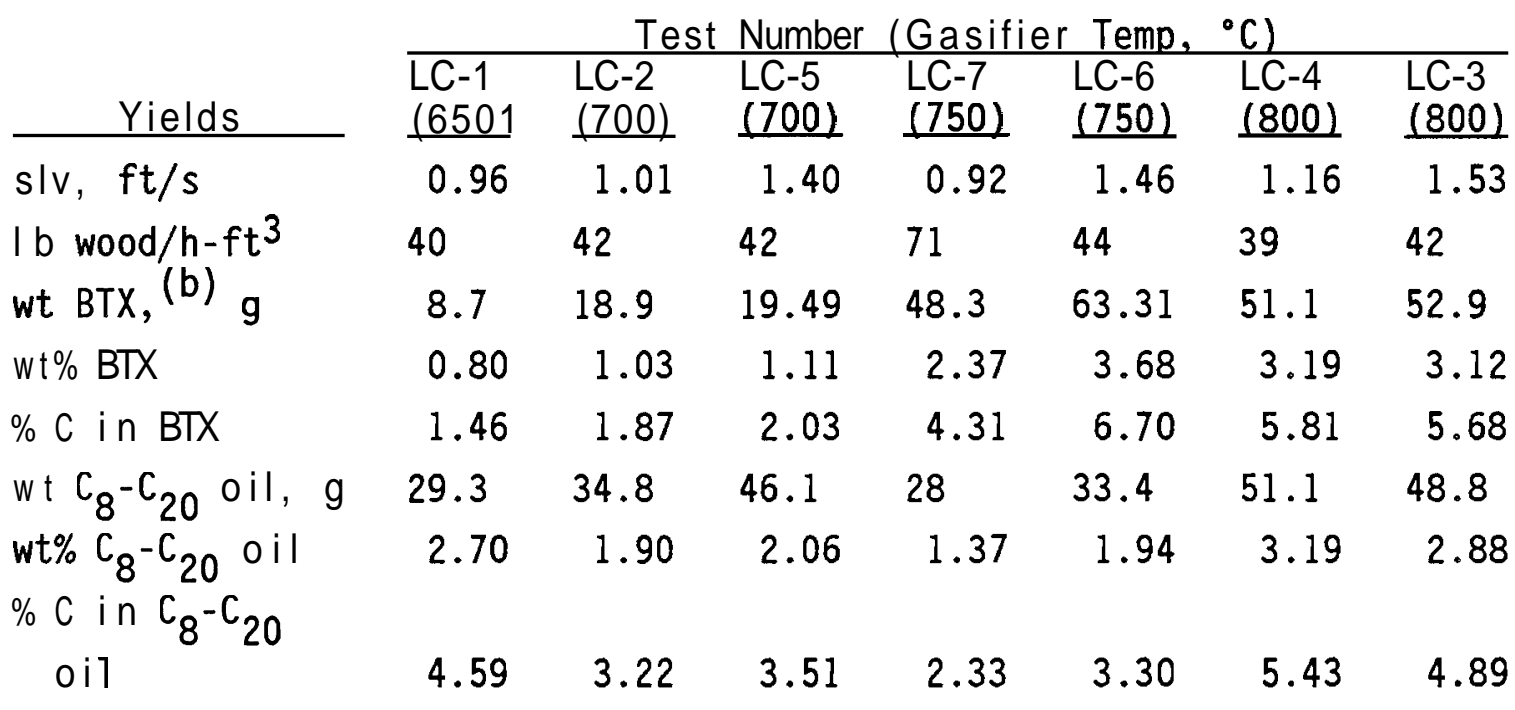

(a) All yields are based on weight of wood feed.

(b) Benzene/toluene/xylene. 
TABLE 6. Gas Composition and Yield with Carbon Dioxide Contact Gas

\begin{tabular}{|c|c|c|c|c|c|c|c|}
\hline Yields & $\begin{array}{l}\mathrm{LC}-1 \\
(650)\end{array}$ & $\begin{array}{l}\text { LC- } \\
(700) \\
\end{array}$ & $\begin{array}{l}\text { LC-5 } \\
(700)\end{array}$ & $\begin{array}{l}\text { LC-7 } \\
(750)\end{array}$ & $\begin{array}{l}\mathrm{LC}-6 \\
(750)\end{array}$ & $\begin{array}{l}\text { LC-4 } \\
(800) \\
\end{array}$ & $\begin{array}{l}\text { LC-3 } \\
(800) \\
\end{array}$ \\
\hline $\mathrm{slv}, \mathrm{ft} / \mathrm{s}$ & 0.96 & 1.01 & 1.4 & 0.92 & 1.46 & 1.16 & 1.53 \\
\hline $1 b / h-f t^{3}$ & 40 & 42 & 42 & 71 & 44 & 39 & 42 \\
\hline \multicolumn{8}{|l|}{ Gas Comp, vol\% } \\
\hline $\mathrm{H}_{2}$ & 3.62 & 4.3 & 2.8 & 47.24 & 4.04 & 4.94 & 4.05 \\
\hline $\mathrm{CO}_{2}$ & 67.33 & 63.68 & 70.28 & 49.14 & 68.25 & 59.89 & 65.71 \\
\hline$c_{2}$ & 0.62 & 0.98 & 0.95 & 1.81 & 1.14 & 1.23 & 1.18 \\
\hline $\mathrm{CH}_{4}$ & 2.42 & 2.82 & 2.44 & 5.3 & 2.99 & 3.14 & 2.66 \\
\hline $\mathrm{CO}$ & 8.16 & 11.16 & 10.22 & 19.82 & 12.26 & 14.79 & 13.3 \\
\hline$c_{3}$ & 0.3 & 0.3 & 0.28 & 0.498 & 0.253 & 0.3 & 0.3 \\
\hline$C_{4}$ & 0.1 & 0.1 & 0.1 & 0.1 & 0.1 & 0.1 & 0.1 \\
\hline $\mathrm{N}_{2}$ & 17.59 & 16.25 & 12.12 & 13.85 & 10.16 & 14 & 11.72 \\
\hline $\mathrm{H}_{2} \mathrm{O}$ & 2.39 & 2.39 & 2.47 & 2.47 & 2.65 & 2.39 & 2.39 \\
\hline $\mathrm{g} \mathrm{H}_{2} / 100 \mathrm{~g}$ wood & 0.83 & 0.97 & 0.79 & 1.13 & 1.13 & 1.31 & 1.18 \\
\hline $\mathrm{g} \mathrm{CH}_{4} / 100 \mathrm{~g}$ wood & 4.44 & 5.08 & 5.43 & 6.61 & 6.68 & 6.66 & 6.22 \\
\hline $\mathrm{g} \mathrm{CO} / 100 \mathrm{~g}$ wood & 26.18 & 35.15 & 39.82 & 43.24 & 47.92 & 54.87 & 54.46 \\
\hline $\mathrm{g} \mathrm{CO}_{2} / 100 \mathrm{~g}$ wood & 16.00 & 15.11 & 10.80 & 14.08 & 21.83 & 4.29 & 4.57 \\
\hline
\end{tabular}

\section{TESTS WITH METHANE}

Tests with $\mathrm{CH}_{4}$ contact gas were completed with the flow configuration shown in Figure 2 to improve material accountability. Results of tests with $\mathrm{CH}_{4}$ as the contact gas are summarized in Table 7. The weight yield of condensibles shown in Table 7 was determined as described in the introduction to this section from the weight of condensibles collected at $-4^{\circ} \mathrm{F}\left(-20^{\circ} \mathrm{C}\right)$ in the measured slip stream. The "\% wt yield" shown in Table 7 was determined from the sum of the weight of all products (gases, condensibles at $-4^{\circ} \mathrm{F}$, and char) divided by the weight of the wood feed.

Gas composition and yield with $\mathrm{CH}_{4}$ as the contact gas are given in Table 8. A small error in the measured flow of $\mathrm{CH}_{4}$ will influence the net yield of $\mathrm{CH}_{4}$ only. Negative $\mathrm{CH}_{4}$ yields in Tests $\mathrm{M}-2$ and $\mathrm{M}-3$ are believed to result from an erroneously high measured $\mathrm{CH}_{4}$ flow. Otherwise, the hydrogen 
TABLE 7. Yields with Methane Contact Gas (a)

\begin{tabular}{|c|c|c|c|c|c|c|}
\hline \multirow{2}{*}{ Yields } & \multicolumn{6}{|c|}{ Test Number (Gasifier Temp, ${ }^{\circ} \mathrm{C}$ ) } \\
\hline & $\begin{array}{c}M-3 \\
(650) \\
\end{array}$ & $\begin{array}{c}M-6 \\
(650) \\
\end{array}$ & $\begin{array}{c}M-1 \\
(725) \\
\end{array}$ & $\begin{array}{c}M-4 \\
(725) \\
\end{array}$ & $\begin{array}{c}M-2 \\
(800) \\
\end{array}$ & $\begin{array}{c}M-5 \\
(800) \\
\end{array}$ \\
\hline $\mathrm{slv}, \mathrm{ft} / \mathrm{s}$ & 1.08 & 2.19 & 1.04 & 2.45 & 1.21 & 2.33 \\
\hline gas contact time, $s$ & 1.9 & 0.9 & 1.9 & 0.8 & 1.7 & 0.9 \\
\hline w t methane/wt wood & 1.35 & 1.93 & 0.83 & 2.34 & 0.94 & 1.8 \\
\hline 1b wood $/ \mathrm{h}-\mathrm{ft}^{3}$ & 39 & 55 & 57 & 47 & 54 & 54 \\
\hline wt $\%$ dry gas & 59 & 53 & 69 & 64 & 78 & 78 \\
\hline$\% C$ in gas & 57 & 51 & 66 & 57 & 72 & 71 \\
\hline$\% \mathrm{H}$ in dry gas & 45 & 59 & 67 & 53 & 63 & 67 \\
\hline$\% 0$ in dry gas & 64 & 56 & 75 & 74 & 88 & 89 \\
\hline wt\% char & 6 & 7 & 7 & 5 & 5 & 4 \\
\hline$\% \mathrm{C}$ in char & 10 & 12 & 12 & 9 & 8 & 7 \\
\hline$\% \mathrm{H}$ in char & 1 & 1 & 1 & 1 & 1 & 1 \\
\hline$\% 0$ in char & 2 & 2 & 2 & 2 & 1 & 1 \\
\hline wt\% o il frac & 21 & 23 & 10 & 21 & 17 & 14 \\
\hline$\%$ C in oil & 29 & 31 & 16 & 33 & 29 & 23 \\
\hline$\% \mathrm{H}$ in oil & 23 & 26 & 9 & 22 & 16 & 14 \\
\hline$\% 0$ in oil & 11 & 13 & 2 & 8 & 3 & 3 \\
\hline wt\% aq sol org & 6 & 1 & 3 & 3 & 1 & 1 \\
\hline$\%$ C in aq sol org & 6.41 & 1.24 & 2.55 & 3.03 & 0.99 & 0.91 \\
\hline$\% \mathrm{H}_{2} \mathrm{O}$ & 19 & 17 & 15 & 9 & 5 & 8 \\
\hline$\% \mathrm{H}$ in $\mathrm{H}_{2} \mathrm{O}$ & 33 & 30 & 26 & 15 & 9 & 14 \\
\hline$\% 0$ in $\mathrm{H}_{2} \mathrm{O}$ & 40 & 36 & 31 & 18 & 11 & 16 \\
\hline$\%$ wtyield & 111 & 102 & 104 & 102 & 105 & 104 \\
\hline C balance, \% & 102 & 96 & 97 & 102 & 109 & 102 \\
\hline H balance, \% & 102 & 116 & 104 & 91 & 89 & 95 \\
\hline 0 balance, $\%$ & 117 & 107 & 110 & 102 & 104 & 109 \\
\hline
\end{tabular}

(a) All yields are based on weight of wood feed. 
TABLE 8. Gas Composition and Yield with Methane Contact Gas

\begin{tabular}{|c|c|c|c|c|c|c|}
\hline Yields & $\begin{array}{c}M-3 \\
(650) \\
\end{array}$ & $\begin{array}{c}M-6 \\
(650) \\
\end{array}$ & $\begin{array}{r}M-1 \\
(725) \\
\end{array}$ & $\begin{array}{c}M-4 \\
(725) \\
\end{array}$ & $\begin{array}{c}M-2 \\
(800) \\
\end{array}$ & $\begin{array}{c}M-5 \\
(800) \\
\end{array}$ \\
\hline slv, $\mathrm{ft} / \mathrm{s}$ & 1.08 & 2.19 & 1.04 & 2.45 & 1.21 & 2.33 \\
\hline $7 \mathrm{~b} / \mathrm{h}-\mathrm{ft}^{3}$ & 39 & 55 & 57 & 47. & 54 & 54 \\
\hline
\end{tabular}

Gas Comp, vol\%

$\begin{array}{lcrrrrr}\mathrm{H}_{2} & 4.571 & 2.249 & 7.863 & 3.471 & 9.608 & 5.566 \\ \mathrm{CO}_{2} & 2.732 & 1.682 & 3.549 & 1.437 & 2.607 & 1.555 \\ \mathrm{C} 2 & 3.462 & 0.997 & 3.689 & 0.81 & 4.298 & 1.476 \\ \mathrm{CH}_{4} & 61.476 & 75.135 & 52.225 & 73.593 & 50.127 & 67.595 \\ \mathrm{CO} & 7.29 & 5.569 & 12.655 & 6.992 & 15.719 & 10.803 \\ \mathrm{C} & 0.5 & 0.157 & 0.601 & 0.25 & 0.509 & 0.257 \\ \mathrm{C} 4 & 0.382 & 0.015 & 0.242 & 0.018 & 0.118 & 0.018 \\ \mathrm{~N}_{2} & 16.821 & 9.209 & 15.589 & 8.444 & 14.126 & 8.704 \\ \mathrm{H}_{2} \mathrm{O} & 3.457 & 5.357 & 3.029 & 4.292 & 3.457 & 4.292 \\ \mathrm{~g} \mathrm{H}_{2} / 100 \mathrm{~g} \text { wood } & 1.22 & 0.75 & 1.59 & 1.40 & 2.16 & 1.89 \\ \mathrm{~g} \mathrm{CH}_{4} / 100 \mathrm{~g} \text { wood } & -4.46 & 8.14 & 1.72 & 3.25 & -3.80 & 3.41 \\ \mathrm{~g} \mathrm{CO}_{100 \mathrm{~g} \text { wood }} & 27.13 & 26.05 & 35.73 & 39.40 & 49.39 & 51.42 \\ \mathrm{~g} \mathrm{CO}_{2} / 100 \mathrm{~g} \text { wood } & 10.17 & 7.87 & 10.02 & 8.10 & 8.19 & 7.40\end{array}$

yield would increase more than the values shown. A $5 \%$ decrease in the input flow rate of $\mathrm{CH}_{4}$ in Tests $\mathrm{M}-2$ and $\mathrm{M}-3$ would give positive $\mathrm{CH}_{4}$ yields of 0.9 and $2.3 \mathrm{~g} \mathrm{CH}_{4} / 100 \mathrm{~g}$ wood, respectively. With the $5 \%$ decrease, the net weight yields of total products for Tests $\mathrm{M}-2$ and $\mathrm{M}-3$ would increase to $105 \%$ and $104 \%$, respectively.

Since the measured input flow rate of $\mathrm{CH}_{4}$ influences the gas weight yield and the $\mathrm{C}$ and $\mathrm{H}$ balances, the magnitude of potential error was evaluated. The effect of a $5 \%$ error in the measured $\mathrm{CH}_{4}$ flow rate is shown in Table 9. Measurements of $\mathrm{CH}_{4}$ flow should be within $5 \%$.

The amounts and compositions of oils collected in the condenser/scrubber are given in Table 10 for tests with $\mathrm{CH}_{4}$ as the contact gas. These oils for 
TABLE 9. Effect of Methane Flow on Gas Yield ${ }^{(a)}$

\begin{tabular}{|c|c|c|c|c|c|c|}
\hline Yields & $\begin{array}{r}M-3 \\
(650) \\
\end{array}$ & $\begin{array}{c}M-6 \\
(650) \\
\end{array}$ & $\begin{array}{c}M-1 \\
(725)\end{array}$ & $\begin{array}{c}M-4 \\
(725)\end{array}$ & $\begin{array}{c}M-2 \\
(800) \\
\end{array}$ & $\begin{array}{c}M-5 \\
(800) \\
\end{array}$ \\
\hline meas $\mathrm{L} / \min \mathrm{CH}_{4}$ & 29 & 59 & 26 & 61 & 28 & 54 \\
\hline wt $\%$ dry gas & 59 & 53 & 69 & 64 & 78 & 78 \\
\hline$\% \mathrm{C}$ in gas & 57 & 51 & 66 & 57 & 72 & 71 \\
\hline$\% \mathrm{H}$ in dry gas & 45 & 59 & 67 & 53 & 63 & 67 \\
\hline$\% 0$ in dry gas & 64 & 56 & 75 & 74 & 88 & 89 \\
\hline $\mathrm{L} / \min \mathrm{CH}_{4}+5 \%$ & 30.45 & 61.95 & 27.30 & 64.05 & 29.40 & 56.70 \\
\hline wt $\%$ dry gas & 52 & 44 & 65 & 52 & 73 & 69 \\
\hline$\%$ C in gas & 47 & 37 & 60 & 40 & 65 & 57 \\
\hline$\% \mathrm{H}$ in dry gas & 18 & 22 & 51 & 7 & 44 & 32 \\
\hline$\% 0$ in dry gas & 64 & 56 & 75 & 74 & 88 & 89 \\
\hline $\mathrm{L} / \min \mathrm{CH}_{4}-5 \%$ & 27.55 & 56.05 & 24.70 & 57.95 & 26.60 & 51.30 \\
\hline wt $\%$ dry gas & 65 & 63 & 74 & 75 & 82 & 87 \\
\hline$\% C$ in gas & 67 & 66 & 73 & 75 & 79 & 85 \\
\hline$\% \mathrm{H}$ in dry gas & 71 & 97 & 83 & 98 & 81 & .102 \\
\hline$\% 0$ in dry gas & 64 & 56 & 75 & 74 & 88 & 89 \\
\hline
\end{tabular}

(a) All yields are based on weight of wood feed.

Tests M-1 and M-2 were not analyzed. Condenser/scrubber and the water soluble organics accounted for only a fraction of the condensible organics collected at $-4^{\circ} \mathrm{F}\left(-20^{\circ} \mathrm{C}\right)$, as noted in Table 10, "wt condenser oils/wt $-4^{\circ} \mathrm{F}$ org." Apparently, scrubbing at $-4^{\circ} \mathrm{F}\left(-20^{\circ} \mathrm{C}\right)$ was much more efficient than scrubbing at $80^{\circ} \mathrm{F}\left(27^{\circ} \mathrm{C}\right)$.

Table 11 presents yield of organics collected in the $\mathrm{MeC} 1$ scrubbers (shown as "cold scrub, $0^{\circ} \mathrm{C}$ " in Figure 2) and identified by GC analysis (as $\mathrm{C}_{6}-\mathrm{C}_{20}$ organics) for tests with $\mathrm{CH}_{4}$ contact gas. The yield of these hydrocarbons relative to the total yield of condensible organics at $-4^{\circ} \mathrm{F}\left(-20^{\circ} \mathrm{C}\right)$ is also shown. 
TABLE 10. Condenser 0 il Yield with Methane Contact Gas (a)

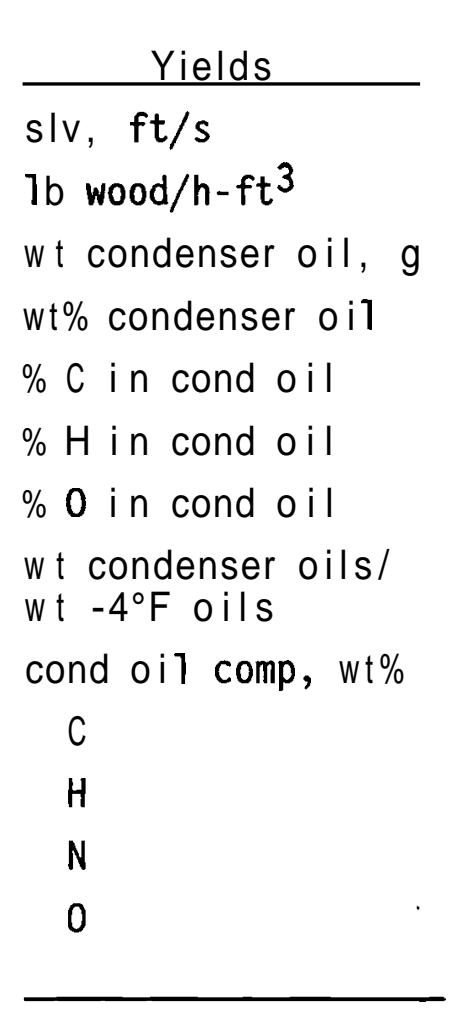

\begin{tabular}{|c|c|c|c|c|c|}
\hline & Test $\mathrm{N}$ & mber ( $G$ & sifier $\mathrm{Te}$ & & \\
\hline $\begin{array}{r}\mathrm{M}-3 \\
(650) \\
\end{array}$ & $\begin{array}{c}M-6 \\
(650) \\
\end{array}$ & $\begin{array}{c}M-1 \\
(725) \\
\end{array}$ & $\begin{array}{c}M-4 \\
(725) \\
\end{array}$ & $\begin{array}{c}M-2 \\
(800) \\
\end{array}$ & $\begin{array}{c}M-5 \\
(800) \\
\end{array}$ \\
\hline 1.08 & 2.19 & 1.04 & 2.45 & 1.21 & 2.33 \\
\hline 39 & 55 & 57 & 47 & 54 & 54 \\
\hline 147 & 214 & 31 & 189 & 126 & 117 \\
\hline 10 & 9 & 5 & 11 & 6 & 5 \\
\hline 13 & 13 & 10 & 18 & 11 & 8 \\
\hline 11 & 10 & 5 & 12 & 6 & 5 \\
\hline 5.38 & 5.38 & 0.60 & 4.09 & 1.32 & 0.93 \\
\hline 0.76 & 0.43 & 0.8 & 0.67 & 0.41 & 0.43 \\
\hline 69.25 & 68.3 & & 77.69 & & 85.18 \\
\hline 7.1 & 7.05 & & 6.74 & & 6.45 \\
\hline 0.11 & 0.33 & & 0.26 & & 0.26 \\
\hline 23.54 & 24.32 & & 15.31 & & 8.11 \\
\hline
\end{tabular}

(a) All yields are based on weight of wood feed.

\section{TESTS WITH HMDROGEN}

Results and conditions of tests with $\mathrm{H}_{2}$ as the contact gas are listed in Table 12. In these tests, the measured flow of input gas had no effect on the calculated yields of $C$ and 0 to the gas phase. Weight of the condensible organics (cond org) was determined from the total condensibles at $-4^{\circ} \mathrm{F}$ $\left(-20^{\circ} \mathrm{C}\right)$, as described above. Carbon accountability and total weight yield was a little lower than desirable in tests at $650^{\circ} \mathrm{C}\left(1200^{\circ} \mathrm{F}\right)$.

Gas composition and yield for tests with hydrogen as the contact gas are shown in Table 13. Error in the measurement of the hydrogen flow rate will influence the yield of $\mathrm{H}_{2}$ only. The negative $\mathrm{H}_{2}$ yield in Test $\mathrm{H}-2$ probably results from an erroneously high value measured for the input hydrogen 
TABLE 11. Yield of Organics in Methylene Chloride with Methane Contact Gas $(a)$

\begin{tabular}{|c|c|c|c|c|c|c|}
\hline Yields & $\begin{array}{l}M-3 \\
(650) \\
\end{array}$ & $\begin{array}{c}M-6 \\
(650) \\
\end{array}$ & $\begin{array}{l}\text { M-1 } \\
(725) \\
\end{array}$ & $\begin{array}{r}M-4 \\
(725) \\
\end{array}$ & $\begin{array}{c}M-2 \\
(800) \\
\end{array}$ & $\begin{array}{r}M-5 \\
(800) \\
\end{array}$ \\
\hline $\mathrm{slv}, \mathrm{ft} / \mathrm{s}$ & 1.08 & 2.19 & 1.04 & 2.45 & 1.21 & 2.33 \\
\hline $1 b$ wood $/ h-f t^{3}$ & 39 & 55 & 57 & 47 & 54 & 54 \\
\hline w t BTX, g & 36 & 57 & 38 & 53 & 48 & 66 \\
\hline wt $\%$ BTX & 2.39 & 2.52 & 2.76 & 3.20 & 2.44 & 2.76 \\
\hline$\%$ C in BTX & 4.37 & 4.60 & 5.05 & 5.84 & 4.46 & 5.04 \\
\hline$w t C_{8}-C_{20}$ oils, $g$ & 26 & 50 & 28 & 27 & 36 & 54 \\
\hline wt $\% C_{8}-C_{20}$ oils & 1.73 & 3.21 & 2.03 & 1.63 & 1.83 & 2.26 \\
\hline$\% C$ in $C_{8}-C_{20}$ & 2.93 & 3.01 & 3.46 & 2.77 & 3.11 & 3.83 \\
\hline $\begin{array}{l}\text { wt } C_{6}^{-}{ }^{-}{ }_{20} \text { oils/ } \\
\text { wt cond } \\
\text { corg }\end{array}$ & 0.2 & 0.2 & 0.5 & 0.2 & 0.3 & 0.4 \\
\hline
\end{tabular}

(a) All yields are based on weight of wood feed.

flow. A $5 \%$ decrease in the input hydrogen flow would increase the calculated $\mathrm{H}_{2}$ net yield to a positive $0.69 \mathrm{~g} / 100 \mathrm{~g}$ wood and give a $100 \% \mathrm{H}$ balance and a $104 \%$ weight yield of products.

The yield of organics collected in the condenser and analyses for $\mathrm{C}, \mathrm{H}$, and 0 are presented in Table 14, along with the ratio to the condensible organics (cond org) collected at $-4^{\circ} \mathrm{F}\left(-20^{\circ} \mathrm{C}\right)$. The amount of organics collected at room temperature ranged from about $30 \%$ to over $50 \%$ of the condensible organics collected at $-4^{\circ} \mathrm{F}\left(-20^{\circ} \mathrm{C}\right)$.

The yield of $\mathrm{C}_{6}$ to $\mathrm{C}_{20}$ in the $\mathrm{MeCl}$ scrub solutions identified by $G C$ analysis are shown in Table 15 . The $G C$ analysis identified organics from $C_{6}$ to $\mathrm{C}_{20}$. 
TABLE 12. Yields with Hydrogen Contact Gas (a)

\begin{tabular}{|c|c|c|c|c|c|c|}
\hline \multirow{2}{*}{ Yields } & \multicolumn{6}{|c|}{ Test Number (Gasifier Temp, ${ }^{\circ} \mathrm{C}$ ) } \\
\hline & $\begin{array}{c}\mathrm{H}-1 \\
(650) \\
\end{array}$ & $\begin{array}{c}\mathrm{H}-3 \\
(650) \\
\end{array}$ & $\begin{array}{c}H-2 \\
(725) \\
\end{array}$ & $\begin{array}{c}\mathrm{H}-4 \\
(725) \\
\end{array}$ & $\begin{array}{c}H-5 \\
(800) \\
\end{array}$ & $\begin{array}{c}H-6 \\
(800)\end{array}$ \\
\hline $\mathrm{slv}, \mathrm{ft} / \mathrm{s}$ & 1.05 & 2.26 & 1.12 & 1.73 & 1.13 & 2.20 \\
\hline $1 b$ wood $/ h-f t^{3}$ & 34 & 69 & 49 & 43 & 40 & 47 \\
\hline wt $\mathrm{H}_{2} /$ wt wood & 0.19 & 0.2 & 0.13 & 0.22 & 0.14 & 0.24 \\
\hline wt\% dry gas & 51 & 38 & 67 & 62 & 78 & 73 \\
\hline$\% C$ to gas & 47 & 33 & 65 & 60 & 76 & 73 \\
\hline$\% \mathrm{H}$ in dry gas & 47 & 53 & 40 & 57 & 60 & 57 \\
\hline$\% 0$ in dry gas & 57 & 44 & 74 & 66 & 84 & 77 \\
\hline wt $\%$ char & 6 & 8 & 8 & 7 & 4 & 3 \\
\hline$\%$ C to char & 10 & 14 & 14 & 11 & 6 & 5 \\
\hline$\% \mathrm{H}$ in char & 1 & 1 & 1 & 1 & 1 & 1 \\
\hline$\% 0$ in char & 2 & 3 & 3 & 2 & 1 & 1 \\
\hline wt $\%$ cond org & 17 & 21 & 14 & 17 & 11 & 10 \\
\hline$\%$ C to oils & 26 & 28 & 22 & 26 & 19 & 18 \\
\hline$\% \mathrm{H}$ in oils & 19 & 25 & 15 & 18 & 12 & 11 \\
\hline$\% 0$ in oils & 7 & 13 & 6 & 6 & 2 & 2 \\
\hline wt $\%$ aq sol org & 5.12 & 9.63 & 2.53 & 3.16 & 0.78 & 0.86 \\
\hline$\%$ C in aq sol org & 5 & 10 & 3 & 3 & 1 & 1 \\
\hline wt $\% \mathrm{H}_{2} \mathrm{O}$ & 15 & 21 & 13 & 11 & 5 & 7 \\
\hline$\% \mathrm{H}$ in $\mathrm{H}_{2} \mathrm{O}$ & 25 & 37 & 23 & 19 & 8 & 11 \\
\hline$\% \mathrm{O}$ in $\mathrm{H}_{2} \mathrm{O}$ & 30 & 45 & 28 & 22 & 10 & 14 \\
\hline$\%$ wt yield & 94 & 99 & 105 & 99 & 98 & 94 \\
\hline C balance, $\%$ & 88 & 84 & 103 & 99 & 102 & 96 \\
\hline $\mathrm{H}$ balance, $\%$ & 92 & 116 & 80 & 95 & 81 & 79 \\
\hline 0 balance, $\%$ & 96 & 104 & 111 & 97 & 97 & 94 \\
\hline
\end{tabular}

(a) All yields are based on weight of wood feed. 
TABLE 13. Gas Composition and Yield with Hydrogen Contact Gas

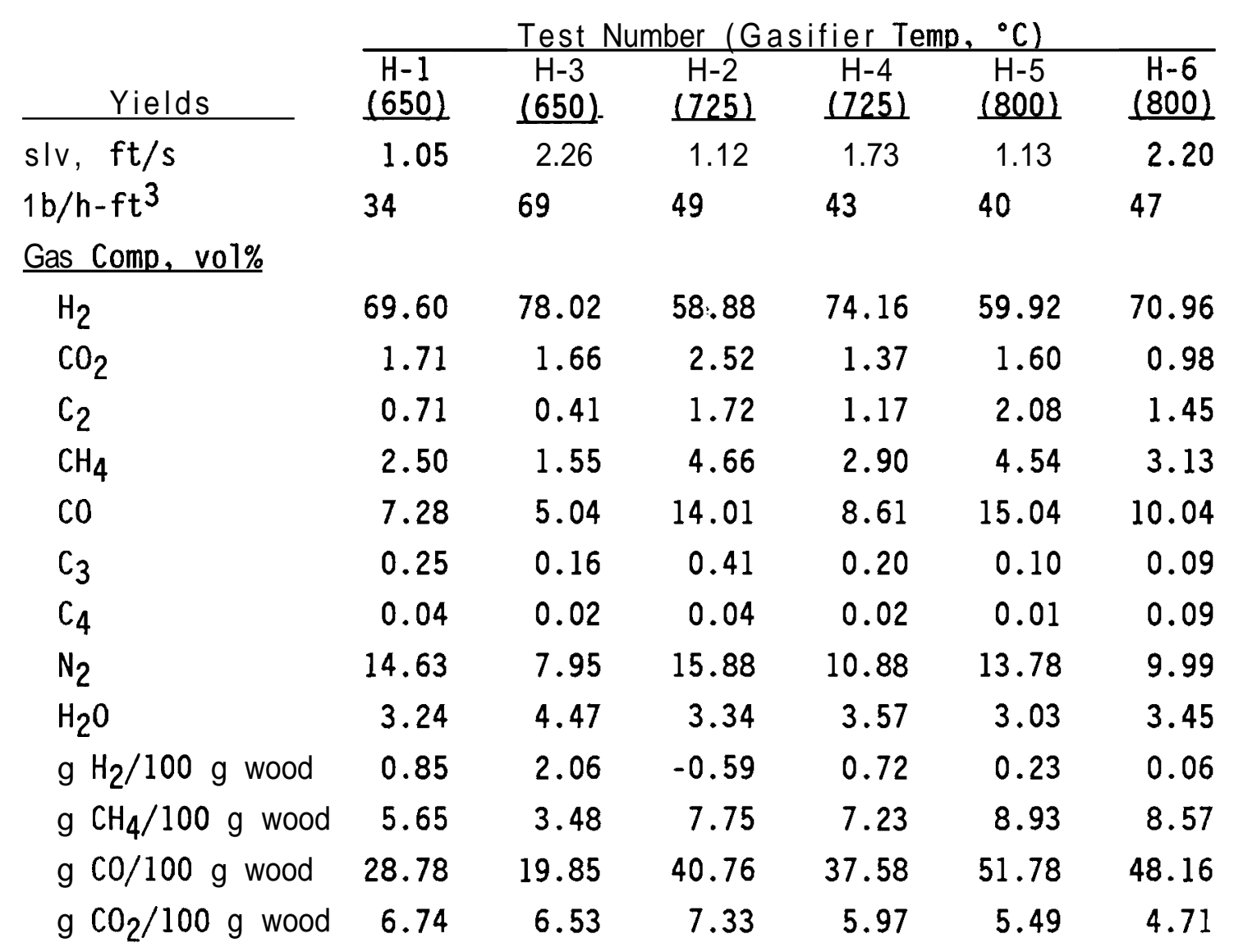


TABLE 14. Yield of Condenser Oils with Hydrogen Contact Gas (a)

\begin{tabular}{|c|c|c|c|c|c|c|}
\hline \multirow[b]{2}{*}{ Yields } & \multicolumn{6}{|c|}{ Test Number (Gasifier Temp, ${ }^{\circ} \mathrm{C}$ ) } \\
\hline & $\begin{array}{c}H-1 \\
(650) \\
\end{array}$ & $\begin{array}{c}\mathrm{H}-3 \\
(650) \\
\end{array}$ & $\begin{array}{c}\mathrm{H}-2 \\
(725) \\
\end{array}$ & $\begin{array}{c}\mathrm{H}-4 \\
(725) \\
\end{array}$ & $\begin{array}{r}H-5 \\
(800) \\
\end{array}$ & $\begin{array}{c}\mathrm{H}-6 \\
(800) \\
\end{array}$ \\
\hline $\mathrm{slv}, \mathrm{ft} / \mathrm{s}$ & 1.05 & 2.26 & 1.12 & 1.73 & 1.13 & 2.20 \\
\hline $1 b$ wood $/ h-f^{3}$ & 34 & 69 & 49 & 43 & 40 & 47 \\
\hline wt condenser o il & 77 & 269 & 100 & 57 & 60 & 95 \\
\hline wt $\%$ condenser oil & 7 & 12 & 7 & 5 & 3 & 4 \\
\hline$\% \mathrm{C}$ in cond oil & 11 & 16 & 10 & 8 & 6 & 7 \\
\hline$\% \mathrm{H}$ in cond oil & 8 & 14 & 7 & 6 & 3 & 4 \\
\hline$\% 0$ in cond oil & 3 & 7 & 3 & 2 & 1 & 1 \\
\hline $\begin{array}{l}\text { wt condenser oils/ } \\
\text { wt }-4^{\circ} \mathrm{F} \text { oils }\end{array}$ & 0.71 & 1.0 & 0.68 & 0.48 & 34 & 0.48 \\
\hline cond o il comp, wt\% & & & & & & \\
\hline C & 74.09 & 66.94 & 79.01 & 77.13 & 85.3 & 85.33 \\
\hline $\mathrm{H}$ & 6.9 & 7.53 & 7.01 & 6.98 & 6.63 & 6.48 \\
\hline$N$ & 0.24 & 0.48 & 0.45 & 0.23 & 0.26 & 0.38 \\
\hline 0 & 17.94 & 25.01 & 18.48 & 15.59 & 7.81 & 7.81 \\
\hline
\end{tabular}

(a) All yields are based on weight of wood feed. 
TABLE 15. Yield of Organics in Meth
with Hydrogen Contact Gas (a) Chloride

\begin{tabular}{|c|c|c|c|c|c|c|}
\hline Yields & $\begin{array}{r}H-1 \\
(650) \\
\end{array}$ & $\begin{array}{r}(650) \\
\end{array}$ & $(725)$ & $\begin{array}{r}7-4 \\
(725) \\
\end{array}$ & $(800)$ & $\begin{array}{r}A-6 \\
(800) \\
\end{array}$ \\
\hline slv, $\mathrm{ft} / \mathrm{s}$ & 1.05 & 2.26 & 1.12 & 1.73 & 1.13 & 2.20 \\
\hline $1 \mathrm{~b}$ wood $/ \mathrm{h}-\mathrm{ft}^{3}$ & 69 & 49 & 43 & 40 & 47 & -- \\
\hline wt BTX, g & 23 & 42 & 29 & 25 & 50 & 58 \\
\hline wt $\%$ BTX & 2.18 & 1.87 & 1.92 & 2.37 & 2.78 & 2.51 \\
\hline$\% C$ in BTX & 3.99 & 3.42 & 3.51 & 4.32 & 5.07 & 4.58 \\
\hline$w t C_{8}-C_{20}$ oil, $g$ & 14 & 39 & 19 & 18 & 25 & 41 \\
\hline$w t \% C_{8}-c_{20} 0 i 1 s$ & 1.33 & 1.74 & 1.26 & 1.70 & 1.39 & 1.77 \\
\hline$\% C$ to $C_{8}-C_{20}$ oil & 2.26 & 2.96 & 2.14 & 2.89 & 2.36 & 3.01 \\
\hline 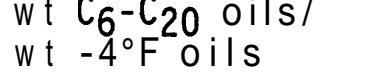 & 0.21 & 0.17 & 0.23 & 0.24 & 0.38 & 0.43 \\
\hline
\end{tabular}

(a) All yields are based on weight of wood feed. 


\section{DISCUSSION OF RESULTS}

The results of the study were analyzed to determine the effects of temperature, contact gas, and gas contact time on the yields of gases, liquids, and chars. These results are based on data from single tests at each set of experimental conditions and show general trends. The significance of these general trends does not justify additional tests at this time.

\section{EFFECT OF TEMPERATURE ON YIELD OF CONDENSIBLES}

The effects of temperature on total yield of condensible organics collected at $-4^{\circ} \mathrm{F}\left(-20^{\circ} \mathrm{C}\right)$ are shown in Figure 3 for $\mathrm{CH}_{4}$ and $\mathrm{H}_{2}$ contact gases. This fraction of condensibles should include al1 condensible organics generated, as described earlier. The yield of these condensible organics decreased with increasing temperature except with $\mathrm{CH}_{4}$ contact gas at $1 \mathrm{ft} / \mathrm{s}$ $(30 \mathrm{~cm} / \mathrm{s})$ slv, which gives a minimum yield at $1340^{\circ} \mathrm{F}\left(725^{\circ} \mathrm{C}\right)$. The same phenomenon was noted for the yield of water-insoluble oils collected at ambient temperature in the condenser (Figure 4). This appears to be experimental error, but material balances were excellent for these tests, as was shown in Table 7.

The yield of condenser oils with a $\mathrm{CH}_{4}$ contact gas (Figure 4) showed a minimum at $1340^{\circ} \mathrm{F}\left(725^{\circ} \mathrm{C}\right)$ with an slv of about $1 \mathrm{ft} / \mathrm{s}(30 \mathrm{~cm} / \mathrm{s})$ (about a $2-\mathrm{s}$ gas residence time) and a maximum at this temperature with an slv of $2 \mathrm{ft} / \mathrm{s}$ $(60 \mathrm{~cm} / \mathrm{s})$. A steady decrease in the amounts of condenser oil occurred with $\mathrm{H}_{2}$ as the contact gas. Material balances were good for the tests with $\mathrm{CH}_{4}$ contact gas (see Table 7).

The yield of water-soluble organics is shown to decrease with temperature in Figure 5, except for the unusually low yield at $1200^{\circ} \mathrm{F}\left(650^{\circ} \mathrm{C}\right)$ for $\mathrm{CH}_{4}$ contact gas at an slv of about $2 \mathrm{ft} / \mathrm{s}$. Experimental error could easily account for this measured low yield.

Figures 6 and 7 illustrate the effect of temperature on the yield of organics collected in the MeCl scrubbers and identified by GC analysis. The data in these figures are for tests with an slv of about $1 \mathrm{ft} / \mathrm{s}$. Figure 6 shows the change in the yield of the BTX fraction, while Figure 7 shows the 


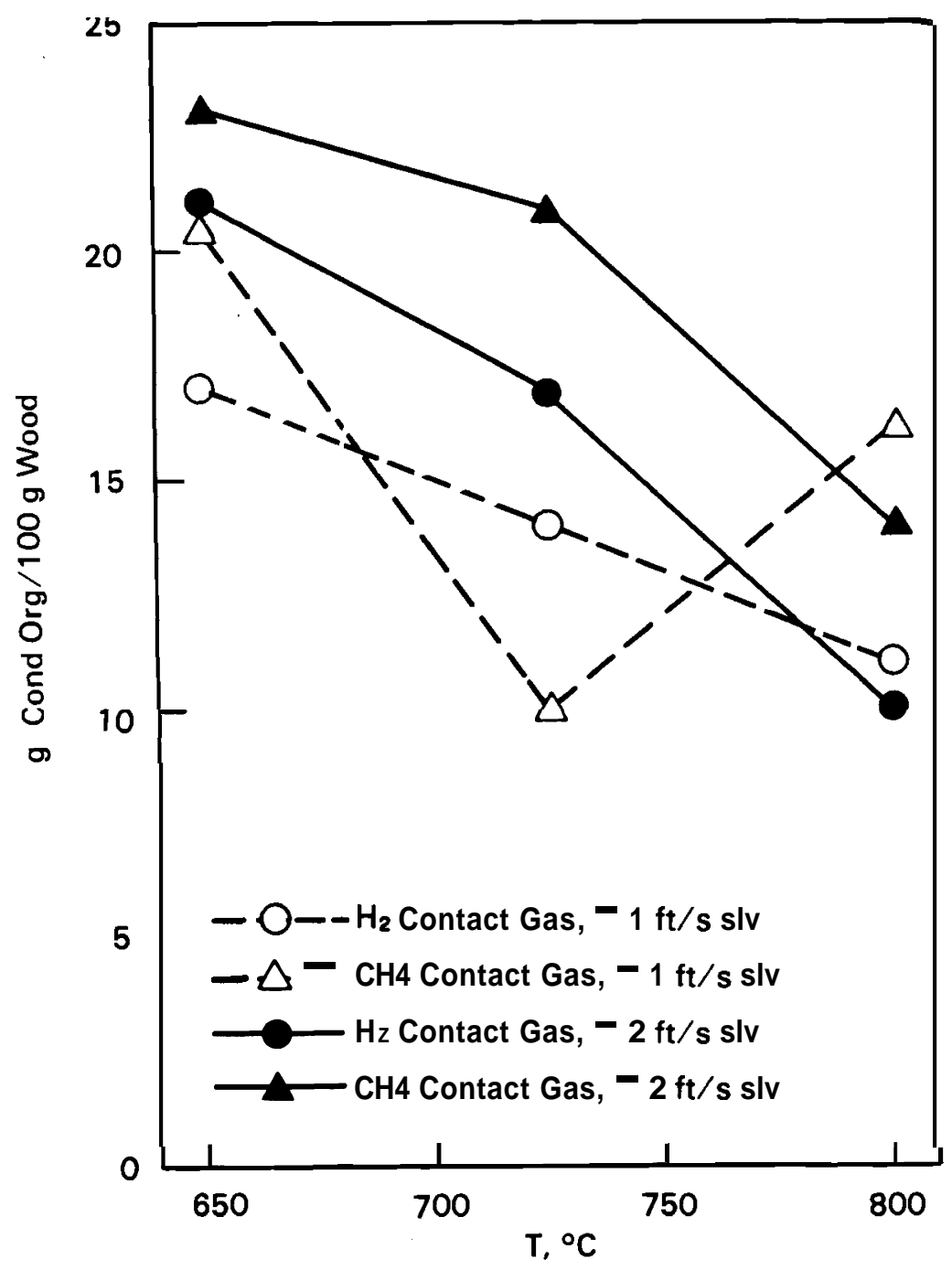

FIGURE 3. Effect of Temperature, Contact Gas, and Gas Velocity on Yield of Condensible Organics

change for all organics collected in the MeCl scrubbers. These figures show a maximum in the yield of these organics at $1340^{\circ} \mathrm{F}\left(725^{\circ} \mathrm{C}\right)$ for $\mathrm{CH}_{4}$ contact gas. Table 11 showed the same maximum for an slv of about $2 \mathrm{ft} / \mathrm{s}$, which indicates a similar trend as in Figure 4 for a shorter gas residence time. Determination of organic yield by independent means showed the same maximum in the yield at $1340^{\circ} \mathrm{F}\left(725^{\circ} \mathrm{C}\right)$ for $\mathrm{CH}_{4}$ contact gas at a gas residence time of 1 s for all fractions collected.

The organic condensibles that could be identified by analysis of the $\mathrm{MeCl}$ scrub solution comprised less than $50 \%$ of the oils collected in the 


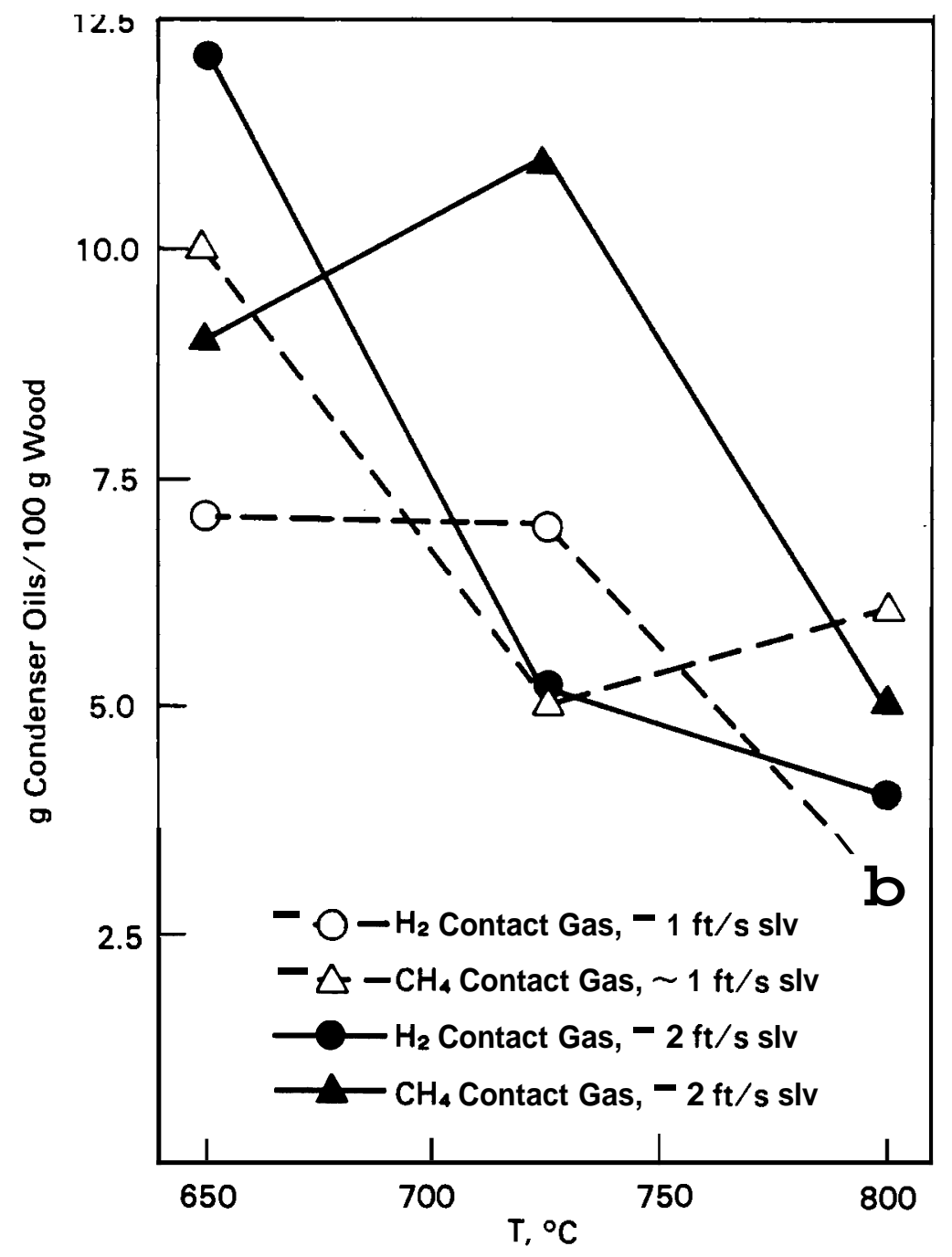

FIGURE 4. Effect of Operating Conditions on Yield of Condenser 0ils

condenser. Condenser oils from three different tests were dissolved in $\mathrm{MeCl}$ to determine the fraction that could be identified by GC analysis. The weight percents of the condenser oils identified are shown in Table 16. This table indicates that $\mathrm{GC}$ analysis of the $\mathrm{MeCl}$ scrub solution did not identify all condensible organics and shows the need for alternative collection systems.

Data from Tables 11, 15, and 16 show that the BTX fraction was not retained in the condenser since this is the major. fraction (over $50 \%$ ) in the $\mathrm{MeCl}$ solutions but a minor fraction $(4 \%$ to $8 \%)$ in the condenser oils. In 


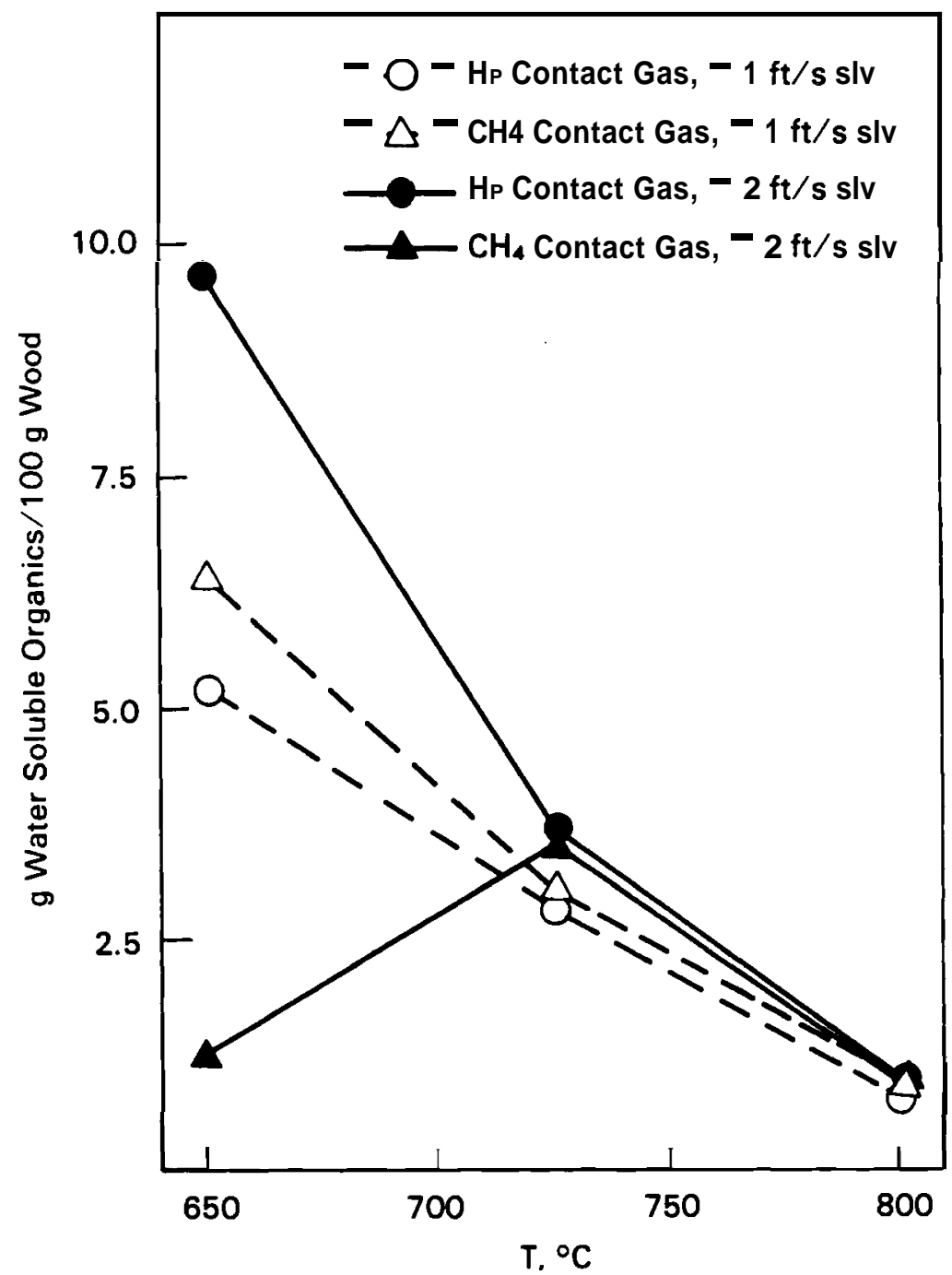

FIGURE 5. Effect of Operating Conditions on Yield of Aqueous Soluble Organics

Tests M-6, $\mathrm{H}-1$, and $\mathrm{H}-6$ the fractions of BTX retained in the condenser oils compared to the $\mathrm{MeCl}$ scrub solutions were $0.15,0.2$, and 0.13 , respectively.

\section{EFFECT OF TEMPERATURE ON GAS YIELD}

The effect of temperature on the total yields of dry gases is shown in Figure 8. As expected, the gas yield increases continuously with temperature. Some of this increase is at the expense of the oil yield and part at the expense of the char yield. Because hydrogen is a light gas, data on gas 


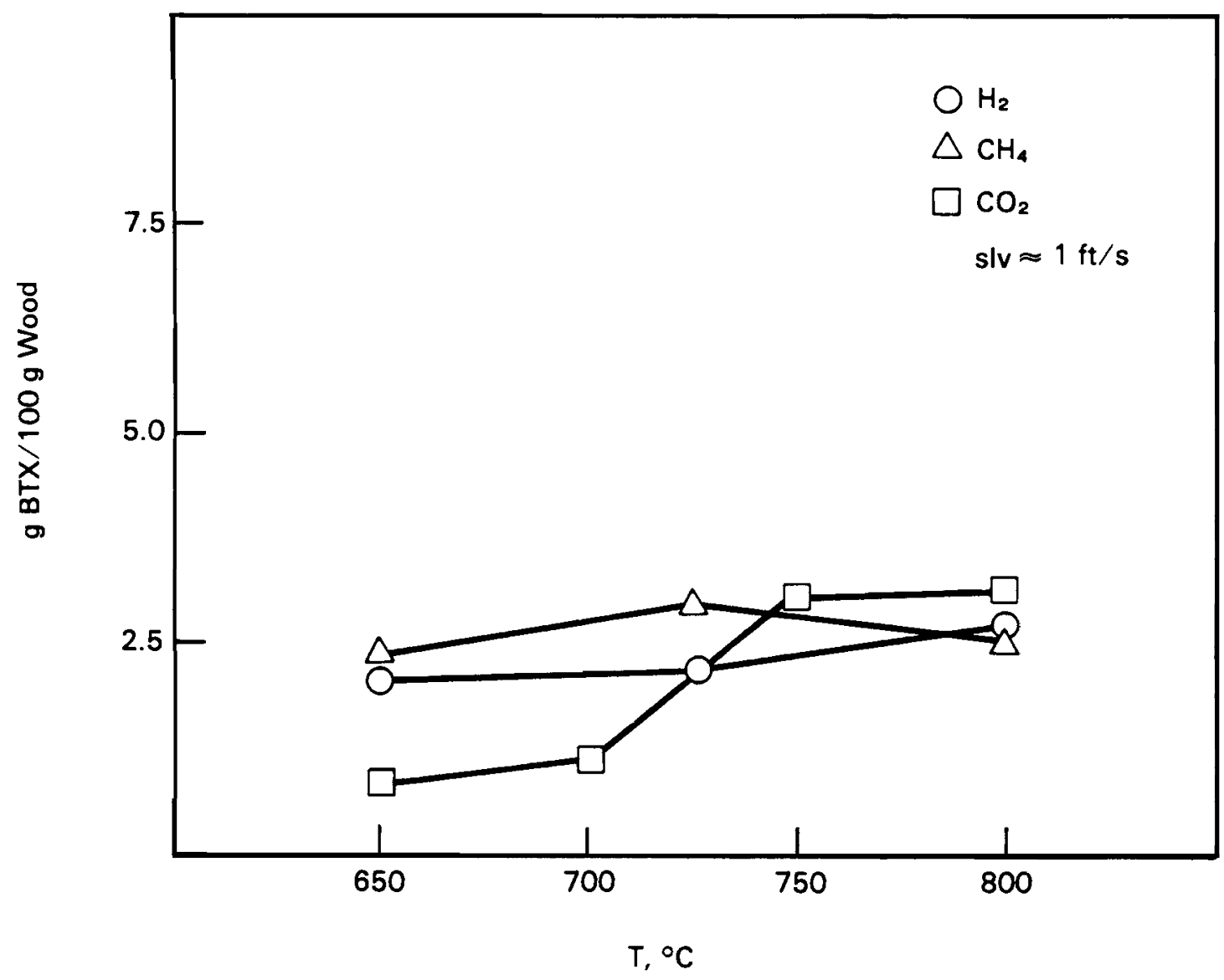

FIGURE 6. Effect of Temperature and Contact Gases on Benzene/Toluene/Xylene Yield in Methylene Chloride Scrub Sol utions

weight yields with hydrogen are expected to be more accurate than data for other gases. Error in the measurement of the input hydrogen flow will not influence the weight yield as much as an error in the flow measurement of other gases, especially $\mathrm{CO}_{2}$.

Figures 9 through 12 show the effect of temperature on the yield of individual gas components, $\mathrm{CO}, \mathrm{CO}_{2}, \mathrm{CH}_{4}$, and $\mathrm{H}_{2}$, respectively. A steady increase in the $\mathrm{CO}$ yield with increasing temperatures is evident for all contact gases. Possible errors in flow measurement made determination of the yield of the contact gas component uncertain, as shown by the erratic results for the contact gases in Figures 10 through 12. It is therefore difficult to determine directly from these data if the contact gas reacts. The yield of $\mathrm{H}_{2}$ shown in Figure 12 indicates that $\mathrm{CH}_{4}$ may react to produce some $\mathrm{H}_{2}$. On 


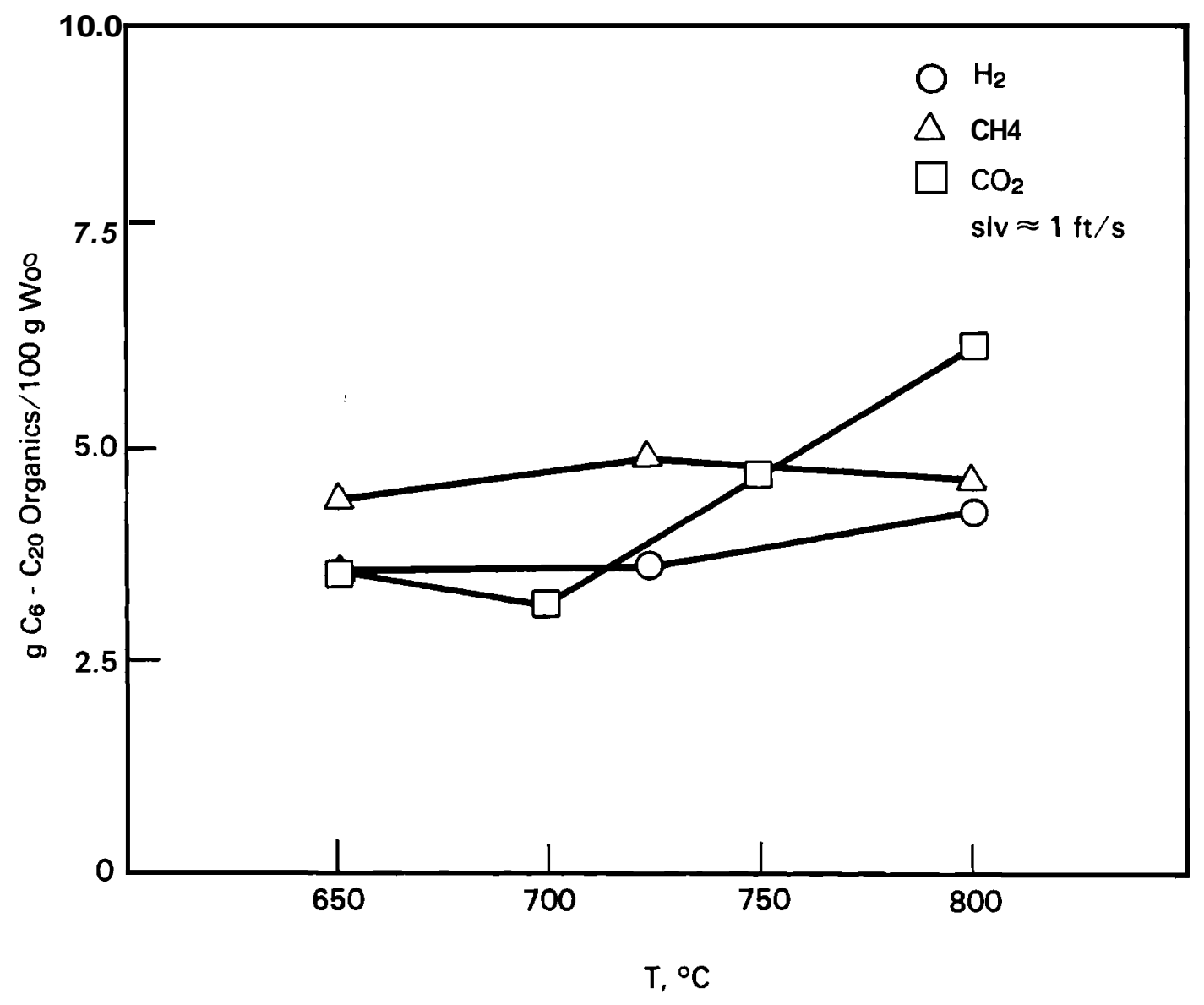

FIGURE 7. Effect of Temperature and Contact Gas on Yield of $\mathrm{C}_{6}-\mathrm{C}_{20}$ Organics

TABLE 16. Percentage of $\mathrm{C}_{6}-\mathrm{C}_{20}$ Components in Condenser $\mathrm{O}$ il Superficial

\begin{tabular}{|c|c|c|c|c|c|c|}
\hline & & Contact & Linear & \multicolumn{3}{|c|}{$\%$ components } \\
\hline Test No. & Temp, ${ }^{\circ} \mathrm{C}$ & Gas & Velocity & $\mathfrak{G}_{6}=\mathbb{G}_{20}$ & BTX & $\underline{C}_{8}-C_{20}$ \\
\hline M-6 & 650 & $\mathrm{CH}_{4}$ & 2.2 & 18 & 4 & 14 \\
\hline$H-1$ & 650 & $\mathrm{H}_{2}$ & 1.1 & 30 & 6 & 24 \\
\hline$H-6$ & 800 & $\mathrm{H}_{2}^{2}$ & 2.2 & 49 & 8 & 41 \\
\hline
\end{tabular}

the other hand, $\mathrm{CO}_{2}$ may consume some $\mathrm{H}_{2}$ to yield $\mathrm{CO}$ (as confirmed by Figure 9), which makes the $\mathrm{H}_{2}$ yield with $\mathrm{CH}_{4}$ appear higher than with $\mathrm{CO}_{2}$ (Figure 12). 


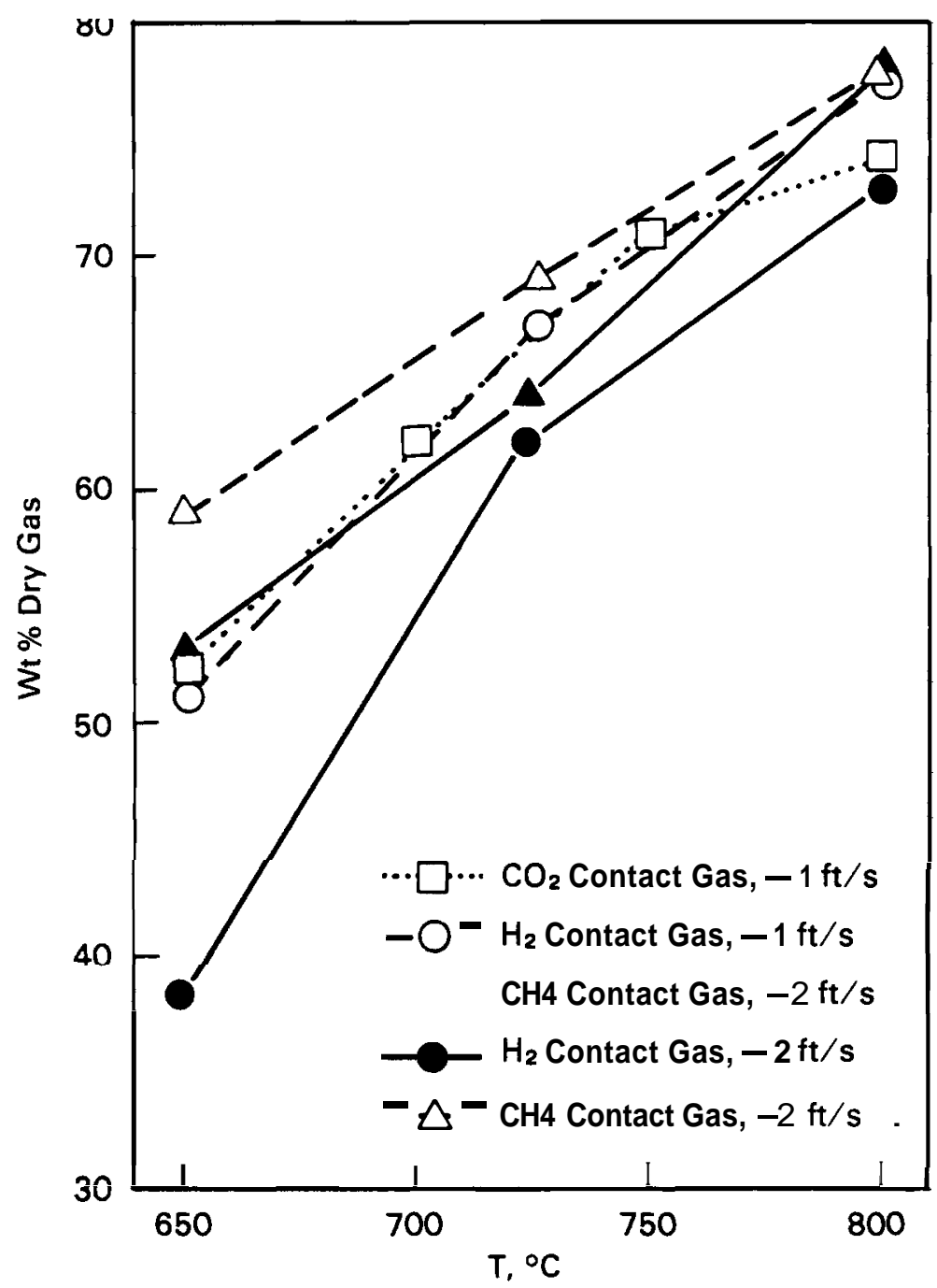

FIGURE 8. Effect of Temperature on Gas Yield

The effect of temperature on the weight yield of char is shown in Figure 13 for tests with different contact gases at 1 and $2 \mathrm{ft} / \mathrm{s} \mathrm{slv}$. Char yi'eld generally decreased with temperature. A maximum in char yield at $1 \mathrm{ft} / \mathrm{s}$ slv occurred with $\mathrm{CH}_{4}$ and $\mathrm{H}_{2}$ contact gases. It appears that this maximum may result from the predominance of reactions that form char in preference to liquids at these conditions. 


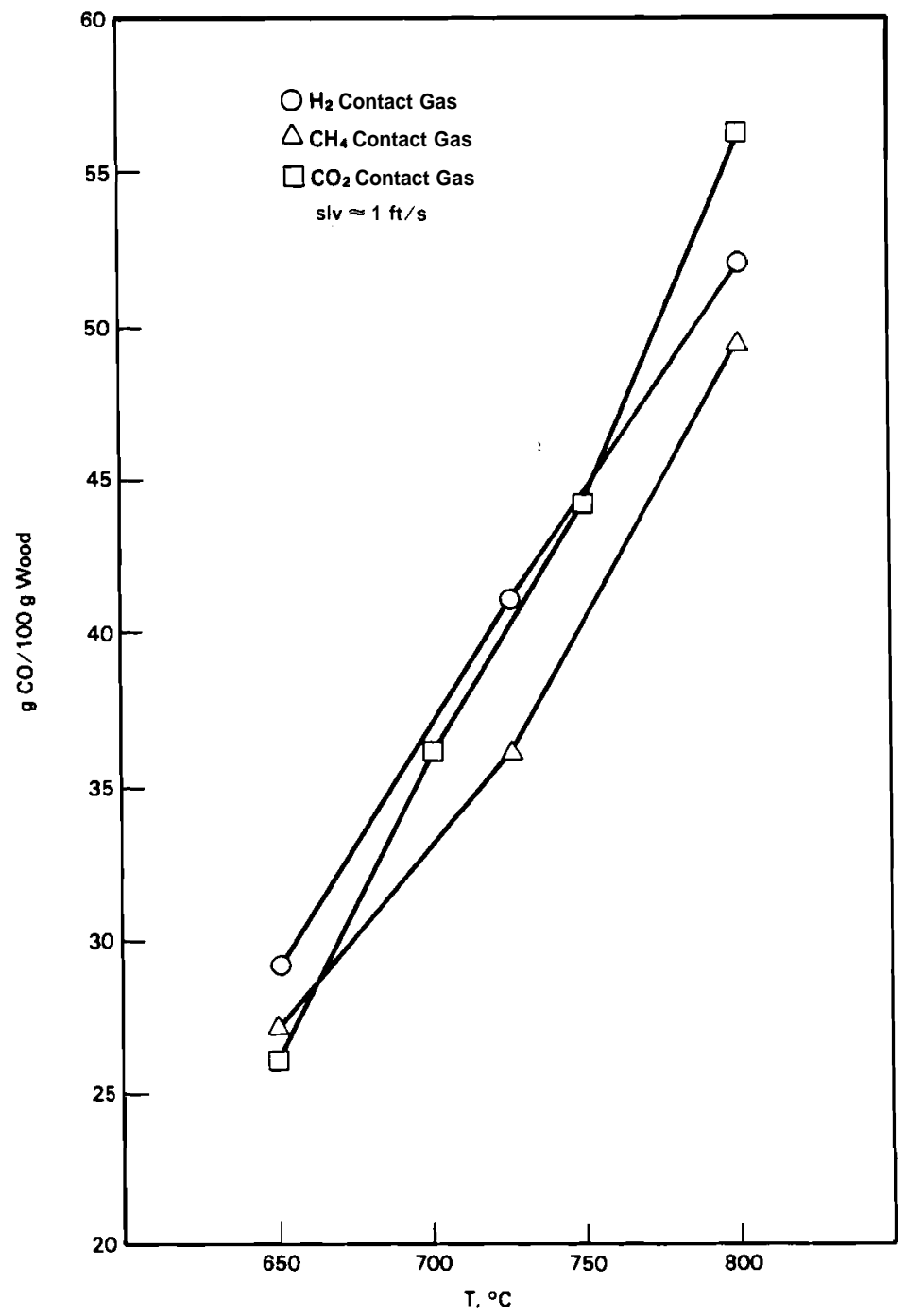

FlGURE 9. Effect of Temperature and Contact Gas on Yield of Carbon Monoxide

\section{EFFECT OF CONTACT GAS}

As noted in the previous discussion, yields of gases, liquids, and char depended on the contact gas as well as the temperature. Tests with $\mathrm{CO}_{2}$ were completed with the dual-vessel system shown in Figure 1. As a consequence, condenser oils were destroyed by the LZ-Y82 catalyst. Also, no condensate was collected at $-4^{\circ} \mathrm{F}\left(-20^{\circ} \mathrm{C}\right)$ with $\mathrm{CO}_{2}$.

In general, the yield of condensible organics was higher with $\mathrm{CH}_{4}$ contact gas than with $\mathrm{H}_{2}$ contact gas. As illustrated in Figure 3, the yield of 


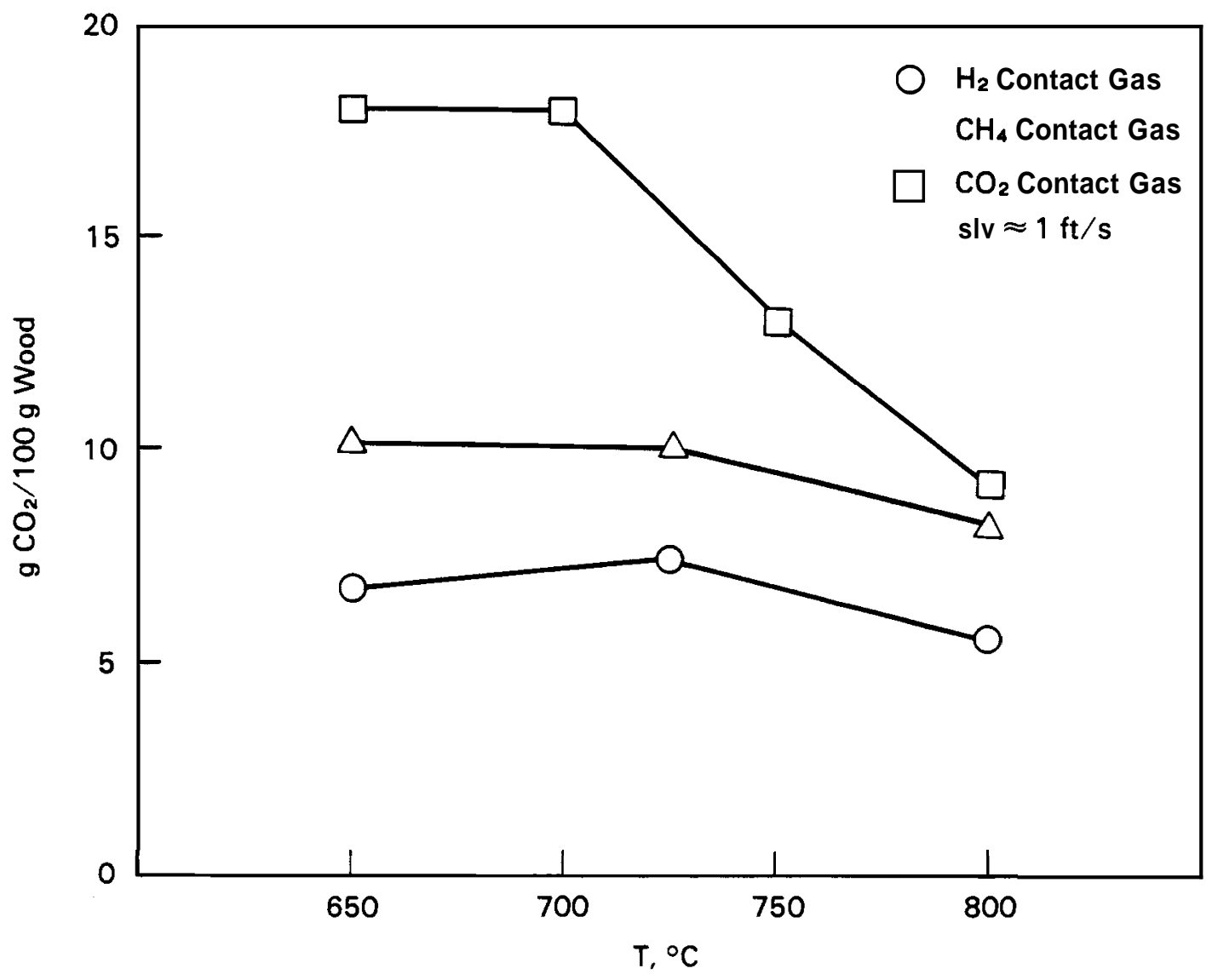

FIGURE 10. Effect of Temperature and Contact Gas on Yield of Carbon Dioxide

total condensible organics collected at $-4^{\circ} \mathrm{F}\left(-20^{\circ} \mathrm{C}\right)$ was greater for $\mathrm{CH}_{4}$ with a 1 -s contact time $\left(2 \mathrm{ft} / \mathrm{s} \mathrm{slv}\right.$ ) than for $\mathrm{H}_{2}$ with a 1 -s contact time. With a 2-s contact time a minimum yield was evident for $\mathrm{CH}_{4}$ gas. In all other cases at similar conditions the yield of total condensible organics with $\mathrm{CH}_{4}$ exceeded the yield with $\mathrm{H}_{2}$.

The yield of oils collected at room temperature in the condenser was also higher with $\mathrm{CH}_{4}$ contact gas than with $\mathrm{H}_{2}$ contact gas except for several tests shown in Figure 4. Again, a low yield with $\mathrm{CH}_{4}$ at $1340^{\circ} \mathrm{F}\left(725^{\circ} \mathrm{C}\right)$ and a 2 -s contact time $(1 \mathrm{ft} / \mathrm{s} \mathrm{slv})$ was apparent. Also, at $650^{\circ} \mathrm{C}$ the yield with $\mathrm{H}_{2}$ and a 1 -s contact time (2 ft/s slv) exceeded the yield with $\mathrm{CH}_{4}$. It should be noted that separation of condenser oils from the aqueous phase is difficult, and these results are from a single test. The trends indicated do not justify additional tests at this time. 


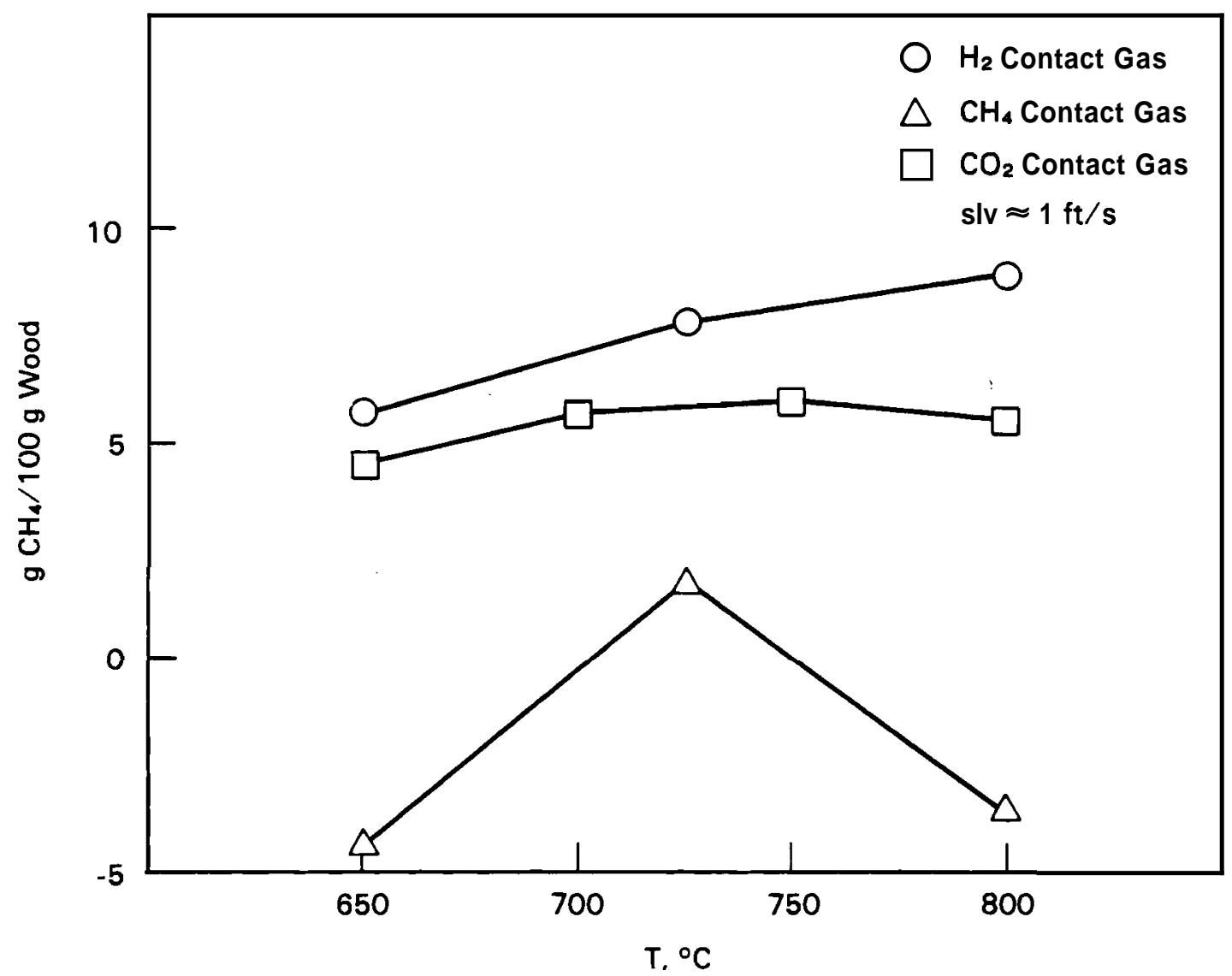

FIGURE 11. Effect of Temperature and Contact Gas on Yield of Methane

The yield of water-soluble organics appears to be unaffected by contact gas at $1340^{\circ} \mathrm{F}$ and $1470^{\circ} \mathrm{F}\left(725^{\circ} \mathrm{C}\right.$ and $800^{\circ} \mathrm{C}$ ) (Figure 5). The unusually low yield for $\mathrm{CH}_{4}$ at a 1 -s contact time and $1200^{\circ} \mathrm{F}\left(650^{\circ} \mathrm{C}\right)$ probably results from experimental error.

Figures 6 and 7 showed that the yields of BTX and $\mathrm{C}_{6}-\mathrm{C}_{20}$ organics were similar, within the accuracy of determination, for $\mathrm{CO}_{2}, \mathrm{CH}_{4}$, and $\mathrm{H}_{2}$ contact gases. Specific components in the organics from the MeCl scrub solutions were not identified, but chromatograms of samples with all contact gases had the same predominant peaks. Essentially no variation in composition was noted with change of contact gas.

In the course of catalyst development studies at PNL, many tests with steam as the'contact gas have been completed in the equipment arrangement 


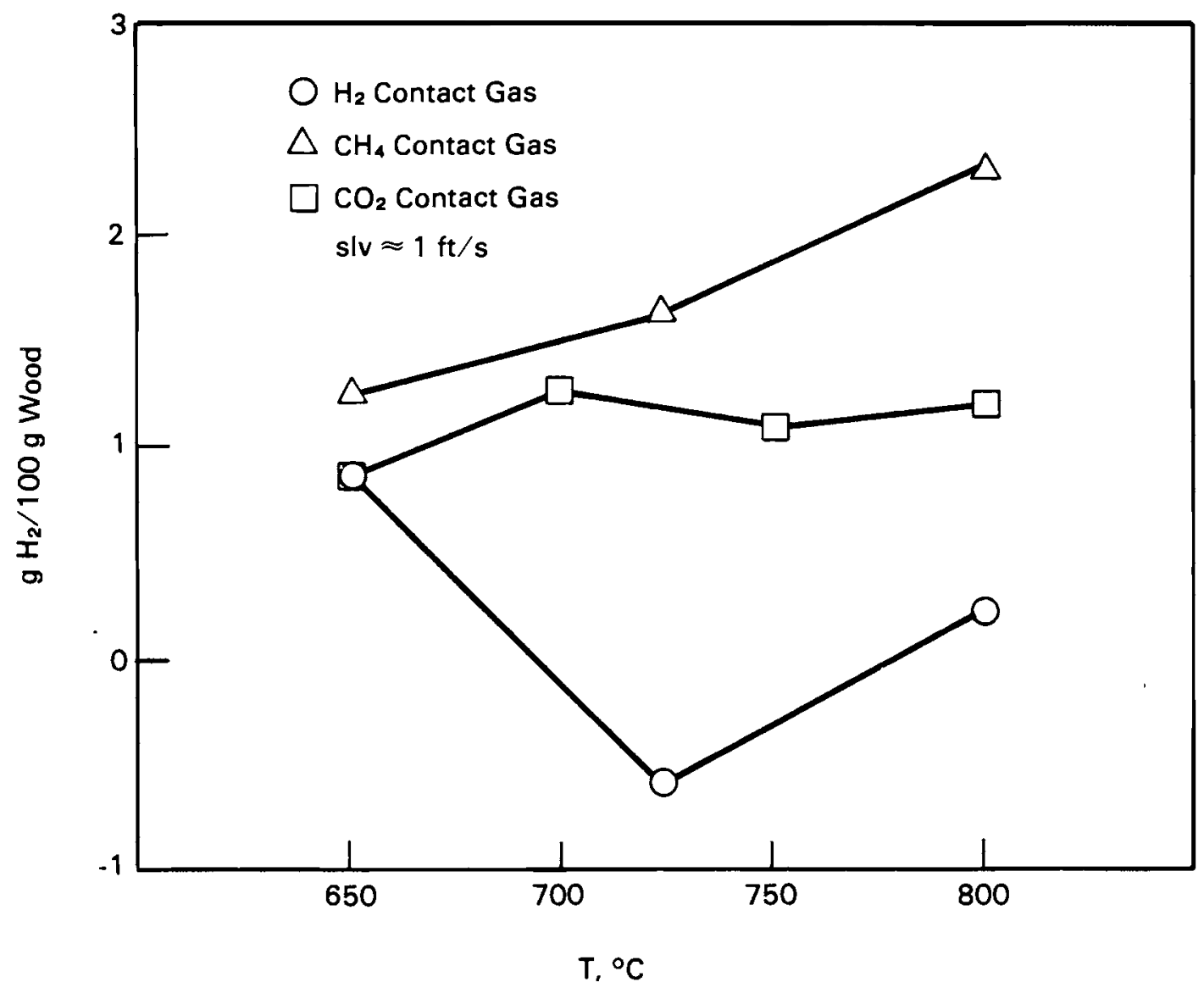

FIGURE 12. Effect of Temperature and Contact Gas on Yield of Hydrogen

shown in Figure 1. These tests were conducted at $1340^{\circ} \mathrm{F}\left(725^{\circ} \mathrm{C}\right)$ with a 2 -s gas residence time. The yield of condensible organics was determined by scrubbing a slipstream with $\mathrm{MeCl}$ at $32^{\circ} \mathrm{F}\left(\mathrm{O}^{\circ} \mathrm{C}\right)$, as described previously. Yields of condensible organics $\left(\mathrm{C}_{6}-\mathrm{C}_{20}\right.$ organics) with steam are compared to $\mathrm{H}_{2}, \mathrm{CH}_{4}$, and $\mathrm{CO}_{2}$ contact gases in Figure 14. At the conditions of these tests, the general trend indicates that yield of these condensible organics was greatest for $\mathrm{CH}_{4}$ contact gas and smallest for $\mathrm{H}_{2}$ and $\mathrm{CO}_{2}$ contact gases. The differences were not very significant. The yield shown for steam in Figure 14 is the average of 15 tests in which the range in yield was from 3.5 to $5 w t \%$.

Analysis of the effect of contact gases on the yield of gas components is complicated by the sensitivity of the calculation of the yield of a 


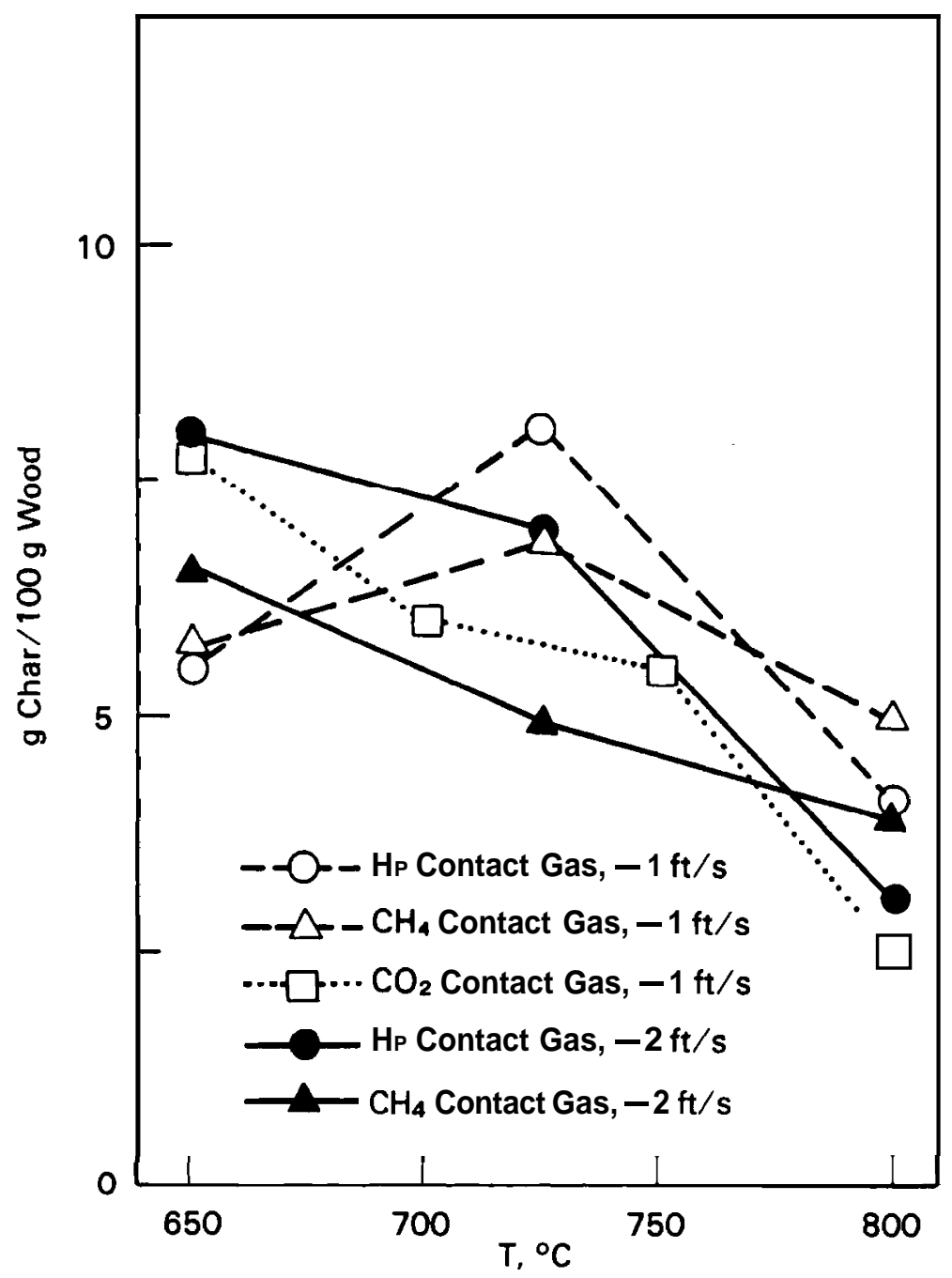

FIGURE 13. Effect of Temperature, Contact Gas, and Gas Velocity on Yield of Char

component to input gas flow rate if that component is the contact gas.

Figures 9 and 12 indicated that the reverse water-gas shift reaction occurs when $\mathrm{CO}_{2}$ and $\mathrm{H}_{2}$ are contact gases, which results in high yield of $\mathrm{CO}$ with $\mathrm{CO}_{2}$ contact gas in Figure 9 and a low yield of $\mathrm{H}_{2}$ with $\mathrm{CO}_{2}$ contact gas in Figure 12.

$$
\mathrm{CO}_{2}+\mathrm{H}_{2} \longrightarrow \mathrm{CO}+\mathrm{H}_{2} \mathrm{O}
$$

Figure 11 showed that the $\mathrm{CH}_{4}$ yield is greater for $\mathrm{H}_{2}$ contact gas than for $\mathrm{CO}_{2}$ contact gas. It appears that additional $\mathrm{CH}_{4}$ to the amount from 


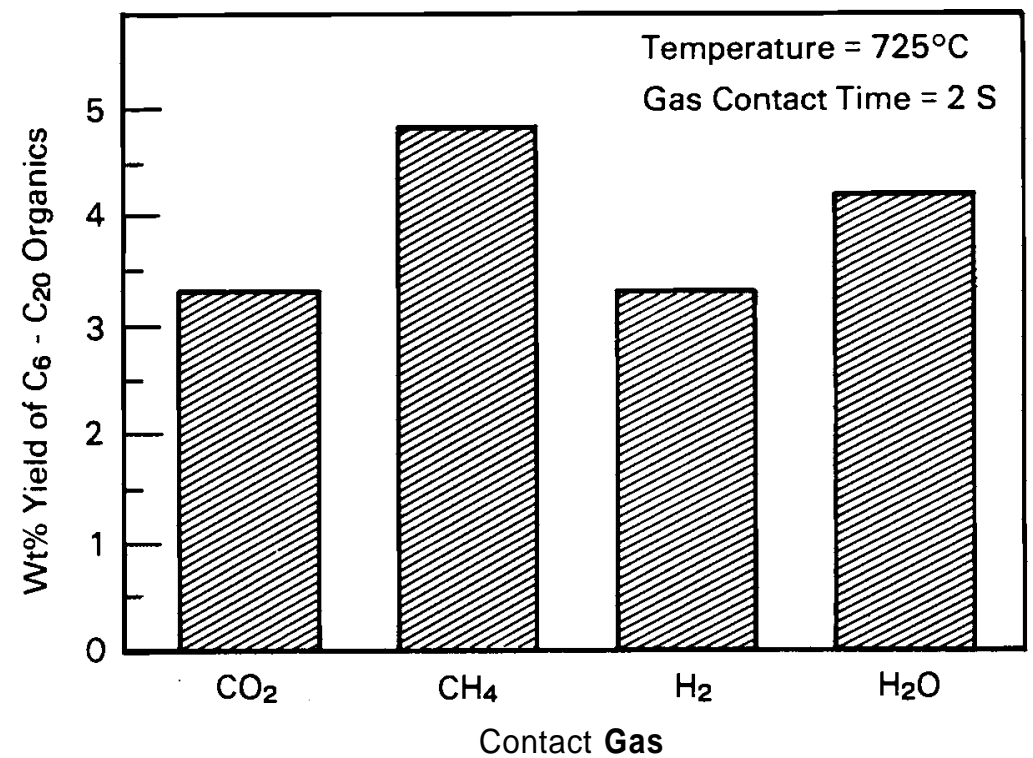

FIGURE 14. Effect of Contact Gas on Yield of Condensible Organics

pyrolysis was formed with $\mathrm{H}_{2}$ as the contact gas. Additional $\mathrm{CH}_{4}$ can be formed by reaction of $\mathrm{H}_{2}$ with char but probably results from $\mathrm{H}_{2}$ preventing $\mathrm{CH}_{4}$ destruction that apparently occurs when $\mathrm{CO}_{2}$ is the contact gas.

No indication of $\mathrm{CH}_{4}$ reaction was directly evident in Figures 9 through 12. Negative $\mathrm{CH}_{4}$ yield with $\mathrm{CH}_{4}$ as the contact gas (Figure 11) probably results from an error in the measurement of the input gas flow rate.

No clear trend for the effect of contact gas on char yield was evident in Figure 13. At $1470^{\circ} \mathrm{F}\left(800^{\circ} \mathrm{C}\right)$ the char yield with $\mathrm{CH}_{4}$ contact gas appeared to be higher than for $\mathrm{H}_{2}$ and $\mathrm{CO}_{2}$. At $1340^{\circ} \mathrm{F}\left(725^{\circ} \mathrm{C}\right)$ yield of char with $\mathrm{H}_{2}$ contact gas was highest. Variation of char-contact gas reaction kinetics with temperature could influence char yield. Differences probably result from experimental error.

\section{EFFECT OF GAS CONTACT TIME}

Gas residence time at reactor temperature, or contact time, was varied from $1 \mathrm{~s}$ to $2 \mathrm{~s}$ with $\mathrm{H}_{2}$ and $\mathrm{CH}_{4}$ gases. High flow rates for a 1 -s contact time could not be maintained with $\mathrm{CO}_{2}$, as discussed previously. 
The effect of residence time on the yield of condensible organics collected at $-4^{\circ} \mathrm{F}\left(-20^{\circ} \mathrm{C}\right)$ was not clear from the data plotted in Figure 3. The yield was higher for a $1-\mathrm{s}$ residence time than for $2 \mathrm{~s}$ at all temperatures except $1470^{\circ} \mathrm{F}\left(800^{\circ} \mathrm{C}\right)$. Oils could be expected to be destroyed at high temperature and increased residence time, but this does not appear to be the case. The same general trend, which could result from experimental error, was also shown in Figure 4 for the yield of condenser oils collected at room temperature. Decreased residence time appeared to increase the yield of water-soluble organics except for $\mathrm{CH}_{4}$ contact gas at $1200^{\circ} \mathrm{F}\left(650^{\circ} \mathrm{C}\right)$, as was shown in Figure 5.

The yield of condensible organics collected in the MeC1 scrubbers, particularly the BTX fraction, was slightly greater at 1-s contact time (2 ft/s slv) than at $2 \mathrm{~s}\left(1 \mathrm{ft} / \mathrm{s}\right.$ slv) at all temperatures with $\mathrm{CH}_{4}$ contact gas, as noted by data in Table 11 . The same consistent trend was not shown by the data in Table 15 for $\mathrm{H}_{2}$ contact gas. Results for $\mathrm{CO}_{2}$ contact gas in Table 5 showed a trend to an increased BTX yield with increased slv (shorter residence time) similar to the data for $\mathrm{CH}_{4}$.

Figure 8 showed that gas yields increase with increased gas residence time, as expected. At temperatures of $1340^{\circ} \mathrm{F}$ and $1472^{\circ} \mathrm{F}\left(725^{\circ} \mathrm{C}\right.$ and $\left.800^{\circ} \mathrm{C}\right)$ the char yield is higher at 2-s residence time than at $\mathrm{I}-\mathrm{s}$ for both $\mathrm{CH}_{4}$ and $\mathrm{H}_{2}$ contact gases (see Figure 13 ), which is somewhat surprising. If both gas and char yields are less at 1-s residence time than at 2-s residence time, then it follows that the liquid yield must be higher at the shorter residence time.

\section{EFFECT OF WOO FEED RATE}

No effort was made to determine the effect of wood feed rate by its systematic variation. Nevertheless, the feed rate, which was determined by weighing the wood before and after each test, did vary substantially. The rate of wood addition to the gasifier was controlled by the rpm of the feed auger.

Usually, but not always, a high input gas rate resulted in a high feed rate. Figure 15 shows the yield of gases as a function of the wood feed rate 


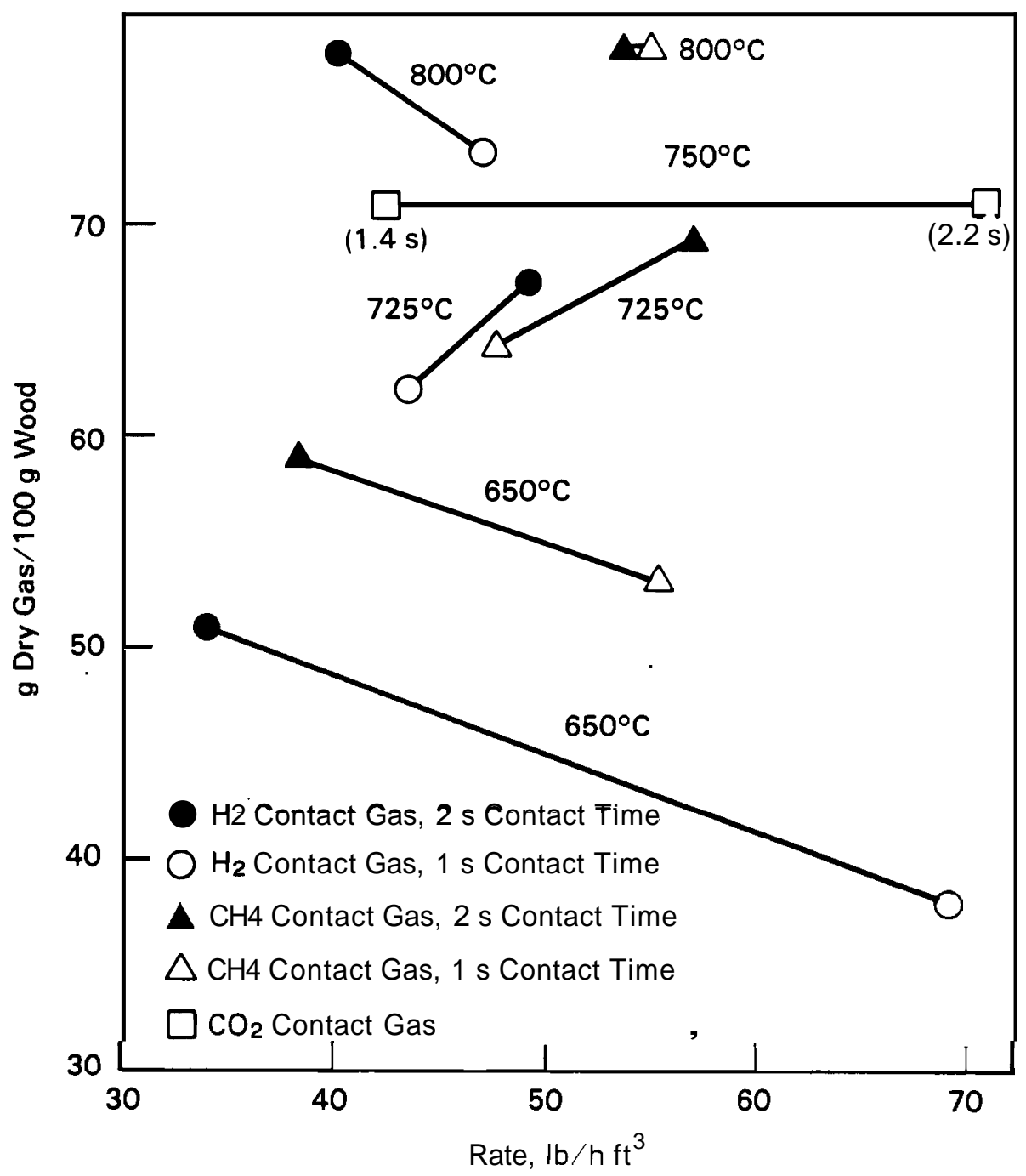

FIGURE 15. Effect of Wood Feed Rate on Gas Yield

(based on fluidized-bed volume) at different temperatures. At each temperature, the gas yield is more a function of gas contact time than wood feed rate. Without exception an increase in the gas contact time results in an increase in gas yield with $\mathrm{H}_{2}$ and $\mathrm{CH}_{4}$ contact gases. For $\mathrm{CH}_{4}$ and $\mathrm{H}_{2}$ the gas yield both increased and decreased with increased wood feed rate, depending on gas contact time. No clear trend for the effect of wood feed rate was evident. 
These results do not conclusively show that wood feed rate does not influence yields. Char residence time (char inventory in the gasifier divided by 0.3 times the wood feed rate) in the tests was in the range of 10 to $30 \mathrm{~min}$, so wood feed rate is probably unimportant. 


\section{CONCLUSIONS AND RECOMMENDATIONS}

Tests with different contact gases for fluid-bed pyrolysis of wood were conducted to determine the effect of these thermal treatment methods on product yields, primarily yield of condensible hydrocarbons. Results of these tests showed slight trends for the effects of temperature, contact gas, and gas contact time on the yields of gases, liquids, and chars. These trends were not significant enough to justify verification by additional tests at this time.

The yield from wood pyrolysis of organics collected in $\mathrm{MeCl}$ scrubbers at $32^{\circ} \mathrm{F}\left(0^{\circ} \mathrm{C}\right)$ was slightly higher for $\mathrm{CH}_{4}$ contact gas than for $\mathrm{H}_{2}$ and $\mathrm{CO}_{2}$ contact gases. The yield of this $\mathrm{C}_{6}-\mathrm{C}_{20}$ organic fraction was similar, within the accuracy of determination, for $\mathrm{H}_{2}$ and $\mathrm{CO}_{2}$ contact gases. The yield with water as the contact gas was slightly less than the yield with $\mathrm{CH}_{4}$ but greater than the yield with $\mathrm{CO}_{2}$ and $\mathrm{H}_{2}$.

Retention, quantification, and identification of condensible hydrocarbons from fluid-bed pyrolysis of wood was extremely difficult. Retention of the BTX fraction in a condenser/scrubber operating at about $77^{\circ} \mathrm{F}\left(25^{\circ} \mathrm{C}\right)$ was found to range from $13 \%$ to $20 \%$ of the amount that was retained in a $\mathrm{MeCl}$ scrubber operating at $32^{\circ} \mathrm{F}\left(0^{\circ} \mathrm{C}\right)$.

For all contact gases, increasing the pyrolysis temperature from $1200^{\circ} \mathrm{F}$ to $1470^{\circ} \mathrm{F}\left(650^{\circ} \mathrm{C}\right.$ to $\left.800^{\circ} \mathrm{C}\right)$ increased gas yield while reducing yields of condensibles and char. The yield of the BTX fraction was fairly constant at about $2.5 \mathrm{~g} / 100 \mathrm{~g}$ wood over this temperature range for all contact gases.

Reduction of the gas residence time from $2 \mathrm{~s}$ to $1 \mathrm{~s}$ showed trends for reduced gas and char yields and increased yield of condensibles.

Some reaction of $\mathrm{H}_{2}$ and $\mathrm{CO}_{2}$ contact gases was evident at temperatures over $1340^{\circ} \mathrm{F}\left(725^{\circ} \mathrm{C}\right)$. The reverse water-gas shift was the main reaction noted.

Yields from wood gasification/pyrolysis were more a function of temperature than contact gas. Some slight trends in yields with different contact gases were noted but were not highly significant. This implies that recycle 
gases (recycled product gases or flue gases) could be used for wood gasification without significantly reducing gas yield at a given operating temperature. Substituting recycle gases for steam could benefit the gasification process by reducing the amount of wastewater. 


\section{REFERENCES}

Baker, E. G., and L. K. Mudge. 1984a. Catalvsis in Biomass Gasification. PNL-5030, Pacific Northwest Laboratory, Richland, Washington.

Baker, E. G., and L. K. Mudge. 1984b. "Mechanisms of Catalytic Biomass Gasification.." Journal of Analvtical and Applied Pvrolvsis 6: 285-297.

Baker, E. G., and L. K. Mudge. 1986. Tar Removal in a Hot Gas Desulfurization Process. DOE/MC/21290-2007 (DE86001054). Avai7able from National Technical Information Service, Springfield, Virginia.

Fritz, J. J., J. J. Gordon, and V. T. Nguyen. 1979. Status Review of Wood Biomass--Gasification, Pvrolvsis, and Densification Technologies. MTR-7900354, Mitre Corporation, McLean, Virginia.

Mitchell, D. H., et a1. 1980. "Methane/Methanol by Catalytic Gasification of Biomass." CEP 76(9):53-57.

Mudge, L. K., L. J. Sealock, Jr., and S. L. Weber. 1979. "Catalyzed Steam Gasification of Biomass. " Journal of Analvtical and Applied Pvrolvsis $1: 165-175$.

Mudge, L. K., R. J. Robertus, D. H. Mitchell, L. J. Sealock, Jr., and S. L. Weber. 1981. Investisations of Catalvzed Steam Gasification of Biomass.

PNL-3695, Pacific Northwest Laboratory, Richland, Washington.

Mudge, L. K., et al. 1983. Catalvtic Gasification Studies in a Pressurized Fluid Bed Unit. PNL-4594, Pacific Northwest Laboratory, Richland, Washington.

Von Fredersdorff, C. G., and M. A. Elliot. 1963. "Coal Gasification." In Chemistrv of Coal Utilization, ed. H. H. Lowry, Supl. Volume, pp. 892-1022. John Wiley and Sons, Inc., New York. 


\section{APPENDIX}

EXPERIMENTAL DATA 
APPENDIX

\section{EXPERIMENTAL DATA}

Experimental data and calculated results of bench-scale tests with different contact gases are tabulated in this appendix. Entries used in the tables are self explanatory in most cases and correspond to terms used in the text. Entries that are not self explanatory are defined below.

Table A. 1 presents results of tests with $\mathrm{CO}_{2}$ contact gas. In these tests a secondary fixed bed of LZ-Y82 catalyst was used to crack tars in the gases from the primary gasifier. Two data columns are used for each test: the first, labeled LC-1 through 7, refers to compositions and yields from the primary gasifier; the second, labeled LC-1P through 7P, refers to compositions and yields from the catalyst bed. Composition and yield of items like char and condensate (cond) have a single value. The weight of condensate includes about $550 \mathrm{~g}$ of water added to the condenser scrubber at the start of each test. Char composition did'not vary much in the tests and was about $85 \mathrm{wt} \% \mathrm{C}, 1 \mathrm{wt} \% \mathrm{H}$, and $14 \mathrm{wt} \% 0$ for the combustible fraction. The weight of char shown in the tables is for the combustible fraction only. Gas flow is measured after the secondary catalytic reactor so the intermediate gas flow from the gasifier is unknown. In Table A.I the intermediate gas flow is assumed to be the same as the product flow in $\mathrm{L} / \mathrm{g}$ of wood.

The LZ-Y82 catalyst effectively destroyed organics in the gas stream such that no water-insoluble phase was collected in the condenser scrubber. Only the condensate from LC-7 was analyzed for total organic carbon, and the two values obtained ( 8900 and $10078 \mathrm{mg} / \mathrm{L})$ are shown in Table A.1.

The $\mathrm{C}_{6}-\mathrm{C}_{20}$ oils were collected in MeCl scrubbers and analyzed on the GC. The BTX is part of these oils.

Tables A.2 and A.3 I is t data from tests with $\mathrm{CH}_{4}$ and $\mathrm{H}_{2}$ contact gases, respectively. The "\% condensibles" shown in these tables refers to the weight collected at $-20^{\circ} \mathrm{C}\left(-4^{\circ} \mathrm{F}\right)$. The "Wtoil fraction, $g$ " is the weight of these condensibles minus the condensate water and water in the gas saturated 
at the condenser temperature. For calculation of yields, this oil fraction was assumed to have the same composition as oils collected in the condenser/ scrubber, which are listed as "wt cond oil." The "wt oils, g" includes the non-BTX fraction collected in the $\mathrm{MeCl}$ scrubbers. The " $\mathrm{WtH}_{2} \mathrm{O}, \mathrm{g}$ " includes condenser water and water in the gas saturated at condenser temperature.

Table entries are defined below:

$\mathrm{CO}_{2} /$ Wood, $\mathrm{g} / \mathrm{g}:$

$\mathrm{CO}_{2} \mathrm{C} /$ Wood C:

$\mathrm{CO}_{2}$ O/Wood 0 :

$\mathrm{slv} / \mathrm{ft} / \mathrm{sec}$ :

$\mathrm{lb} / \mathrm{hr}-\mathrm{ft} \mathrm{t}^{3}$ :

W t wood, g:

Gas flow, 1/g:

Wt \% dry gas:

$\% C$ to gas:

$\% \mathrm{H}$ in dry gas:

$\% 0$ in dry gas:

$\mathrm{g} \mathrm{H}_{2} / 100 \mathrm{~g}$ wood:

$\mathrm{g} \mathrm{CH}_{4} / 100 \mathrm{~g}$ wood:
The weight ratio of contact gas rate $\left(\mathrm{CO}_{2}\right.$ in this listing) to wood rate.

Weight ratio of elemental carbon in the $\mathrm{CO}_{2}$ contact gas to elemental carbon in the wood feed.

Weight ratio of elemental oxygen in the $\mathrm{CO}_{2}$ contact gas to elemental oxygen in the wood feed.

Superficial linear velocity of the contact gas calculated from its volumetric flow rate divided by the cross-sectional area of the gasifier.

Wood feed rate in pounds per hour per cubic foot of fluid-bed volume.

Weight of wood in grams fed to the gasifier during the test.

Total volume of product gas in liters measured by the wet test meter divided by the grams of wood fed to the gasifier.

Weight of product gas (excluding water) times 100 divided by the weight of wood fed to the gasifier.

The percent of wood carbon found in the product gas.

The percent of wood hydrogen that goes to the product gas, excluding water.

The percent of wood oxygen that goes to the product gas, excluding water.

Weight of hydrogen in the product gas in grams for every 100 grams of wood fed to the gasifier.

Same as the preceding entry but for methane. 
g Co/100 g wood:

$\mathrm{g} \mathrm{CO}_{2} / 100 \mathrm{~g}$ wood:

Btu $\mathrm{H}_{2} / 1 \mathrm{~b}$ wood:

Btu $\mathrm{CH}_{4} / \mathrm{lb}$ wood:

Btu CO/1b wood:

$\%$ Btu in gas:

Char yield, g:

Char in bed, g:

$\%$ C to char:

$\% \mathrm{H}$ to char:

$\% 0$ to char:

Min char res $\mathrm{t}$ :

Total cond, g:

$\%$ condensibles:

$\%$ char:

$\%$ wt yield:

W t oil fraction:

$\%$ C to oil:
Same as preceding entry but for carbon monoxide.

Same as preceding entry but for carbon dioxide.

Energy content of hydrogen (in Btu) in product gas per pound of wood fed to the gasifier.

Same as preceding entry but for methane in product gas.

Same as preceding entry but for carbon monoxide in product gas.

Energy content of gas relative to the combustible energy content of the wood, also known as cold gas efficiency.

Weight of char (in grams) accumulated during the test.

The average char inventory in the fluid bed, or one half the sum of the starting and final char inventory in the fluid bed.

The percent of elemental carbon in the wood that is contained in the char yield.

Same as preceding entry but for elemental hydrogen in the wood.

Same as preceding entry but for the elemental oxygen in the wood.

Minutes of char residence time in the fluid bed calculated by dividing the weight of char in the fluid bed by $30 \%$ of the wood feed rate.

Total weight of condensibles (including water) collected at $-4^{\circ} \mathrm{F}\left(-20^{\circ} \mathrm{C}\right)$.

The preceding entry times 100 divided by the weight of wood fed to the gasifier.

The percent of wood converted to char.

The weight percent of the wood fed to the gasifier collected as dry gases, condensibles, and char.

Weight (in grams) of condensibles collected at $-4^{\circ} \mathrm{F}$ $\left(-20^{\circ} \mathrm{C}\right)$ minus the condenser water and water vapor.

Weight percent of the wood carbon in the preceding condensibles. 
$\%$ H to oil:

$\% 0$ to oil:

Wt cond oi $1, \mathrm{~g}$ :

$\% \mathrm{C}$ in cond oil:

$\% \mathrm{H}$ in cond oil:

$\% 0$ in cond oil:

Wt $\mathrm{C}_{6}-\mathrm{C}_{20}$ oils:

\% C to $\mathrm{C}_{6}-\mathrm{C}_{20}$ oils:

$\%$ H to $C_{6}-C_{20}$ oils:

$\% 0$ to $C_{6}-C_{20}$ oils:

Wt oils, g:

$\%$ C to oils:

Wt condensate, $g$ :

Wt cond, $g$ :

TOC, $\mathrm{mg} / 1$ :
Same as preceding entry but for hydrogen.

Same as preceding entry but for oxygen.

Weight in grams of condensibles collected in the condenser/scrubber operating at ambient temperature.

Weight percent of wood carbon in the preceding condensi bl es.

Same as preceding entry but for hydrogen.

Same as preceding entry but for oxygen.

The weight of organics (including BTX) collected and identified in the MeCl scrubbers.

The percent of wood $C$ in the preceding condensibles.

Same as preceding entry but for hydrogen.

Same as preceding entry but for oxygen.

The weight of organics (excluding BTX) collected and identified in the MeCl scrubbers.

The percent of wood carbon in the preceding fraction.

These two table entries refer to the weight in grams of aqueous condensate collected in the condenser/scrubber.

The total organic carbon in the condensate. 
TABLE A:. FESU1

Date number-y

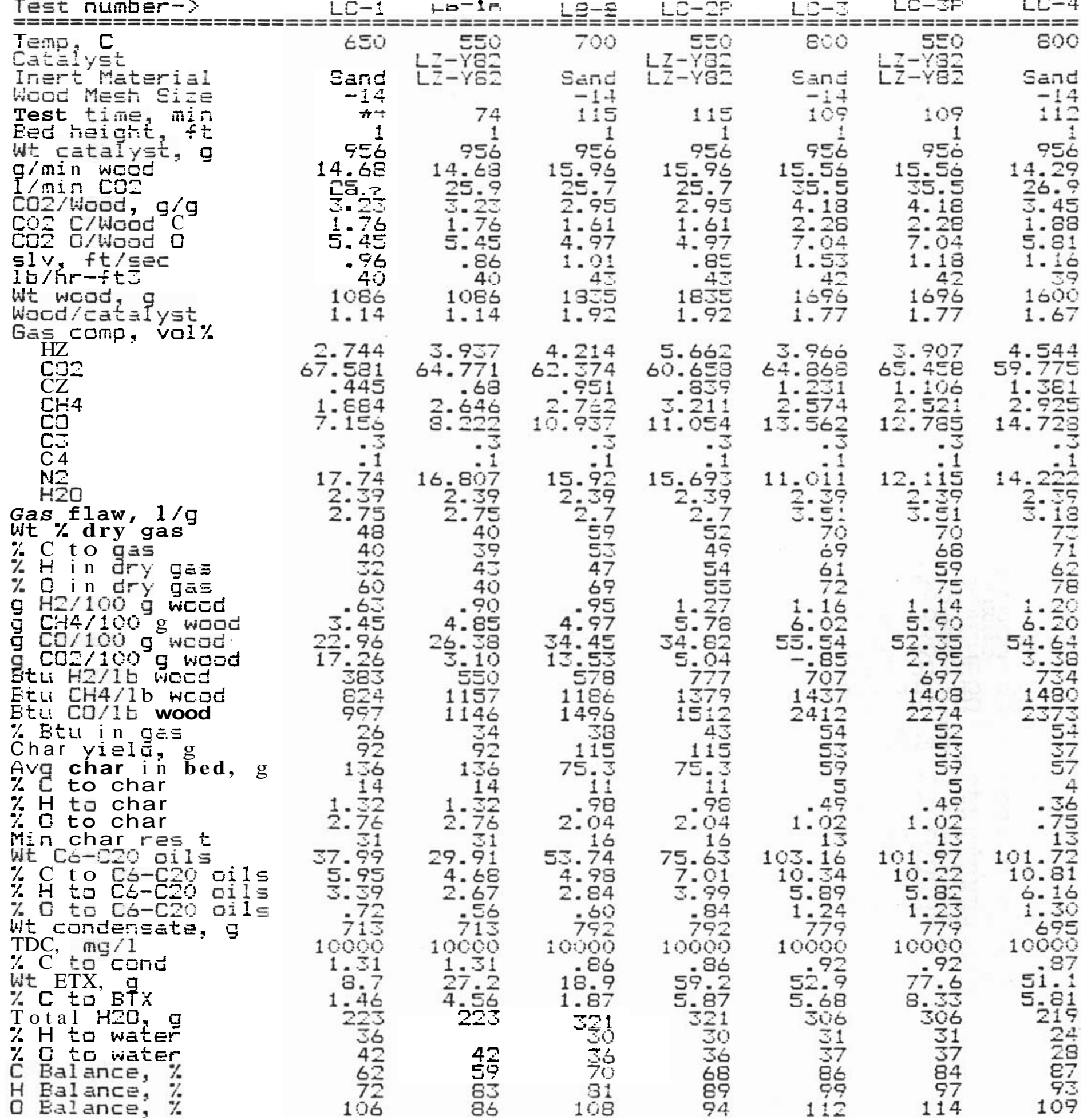


TABLE A1. FEsilts of Tests with Carbon Lioxide Cuntact Gas (contiriled)

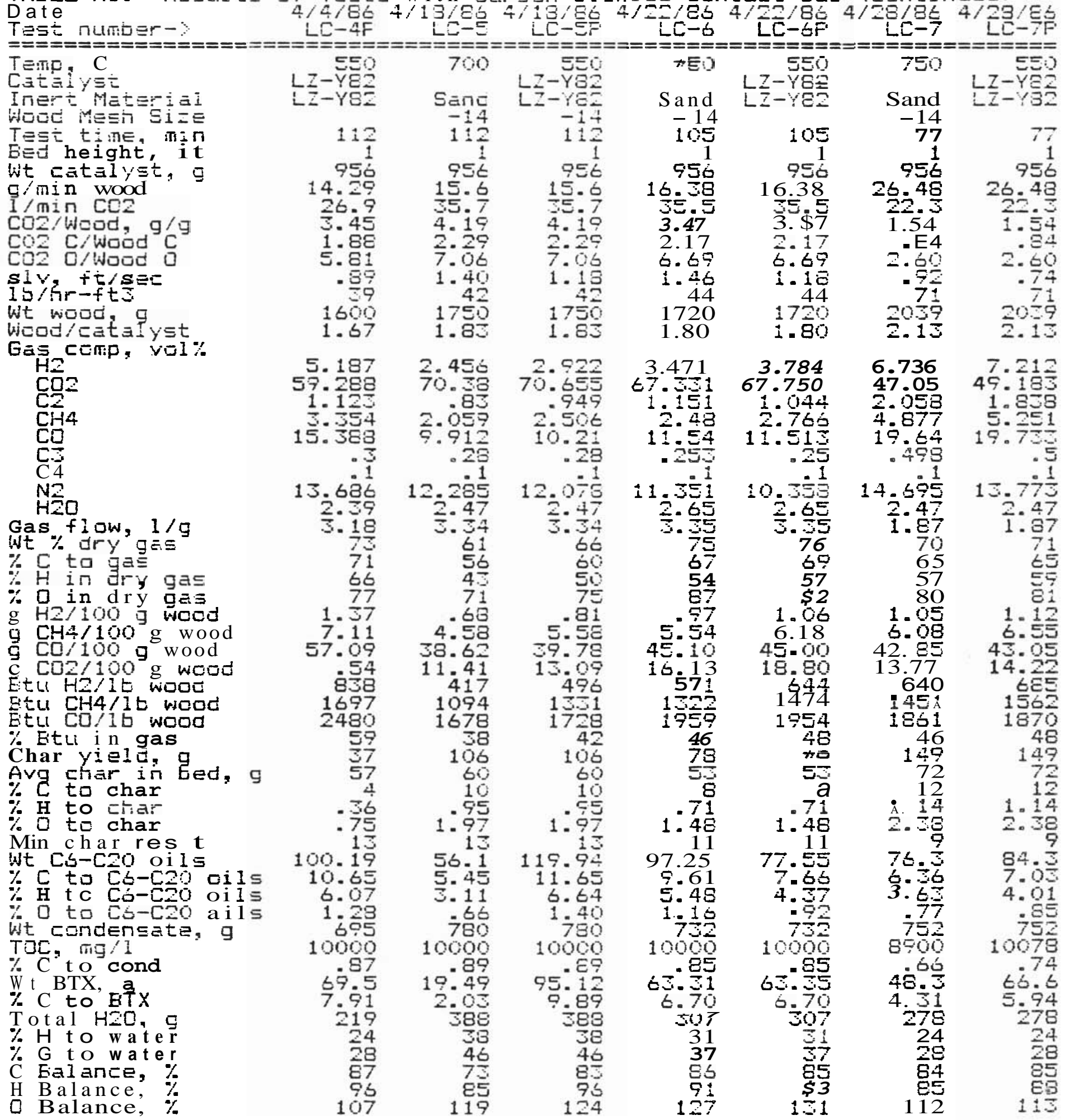




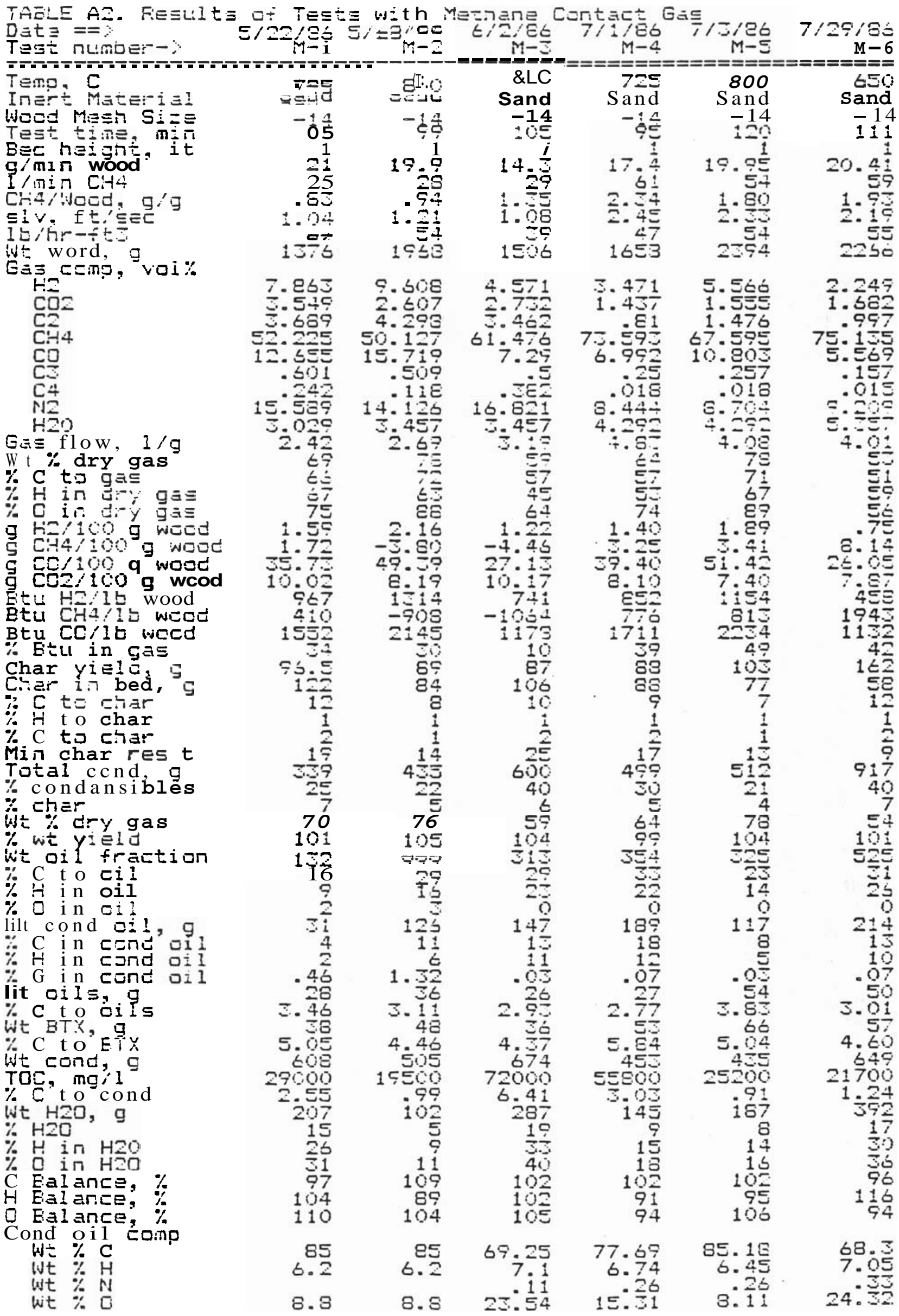




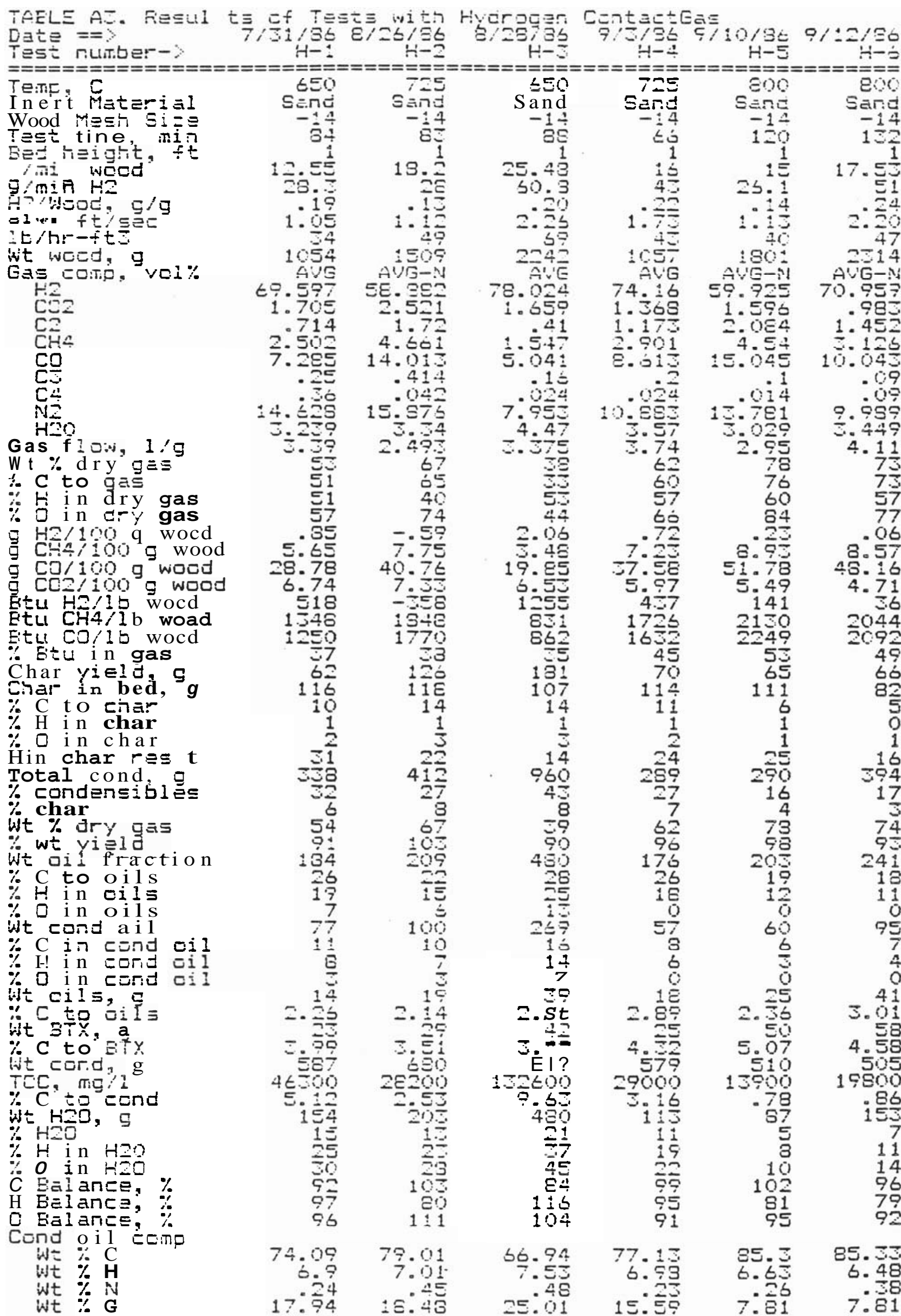




\section{DISTRIBUTION}

No. of

Copies

OFFSITE

D. K. Walter

U. S. Department of Energy

Biofuels and Municipal Waste Technology Division

Forrestal Building

1000 Independence Avenue

Washington, $\mathbb{C} 20545$

2 Simon Friedrich

-U.S. Department of Energy

Biofuels and Municipal Waste Technology Division

Forrestal Building (DE-321)

1000 Independence Avenue

Washington, D 20545

10 DOE Office of Scientific and Technical Information
No. of

$\underline{\text { Cooies }}$

ONSITE

2 DOE Richland Operations Office

D. R. Segna

J. J. Sutey

37 Pacific Northwest Laboratorv

E. G. Baker

M. D. Brown

M. A Gerber

R. S. Kemper

L. K. Mudge (20)

G. F. Schiefelbein (2)

L. J. Sealock, Jr.

D. J. Stevens

P. C. Walkup

W. A. Wilcox

Publishing Coordination (2)

Technical Report Files (5) 